\title{
SISTEMSKO OKOLJSKO VREDNOTENJE TRAJNOSTNEGA RAZVOJA POSELITVENIH OBMOČIJ MESTNE OBČINE KRANJ
}

\author{
dr. Štefan Žun
}

Spodnje Duplje Ie, SI-4203 Duplje

e-mail: stefan.zun@guest.arnes.si

Izvirni znanstveni članek

COBISS 1.01

DOI: $10.4312 /$ dela.42.2.21-49

\section{Izvleček}

S pomočjo metod merjenja trajnostnega razvoja ekoloških sledi (ES) in okoljskega prostora (OP), ki smo jih empirično preizkusili na treh tipih geografskih območij mestne občine, smo ugotovili stopnjo doseženega ne-trajnostnega razvoja v treh vzorčnih geografskih območjih MO Kranj: v strnjenem mestnem jedru (ekološki primanjkljaj 5,44 gha/preb.), na suburbaniziranem območju (ekološki primanjkljaj 7,22 gha/preb.) in okoliškem podeželju (ekološki primanjkljaj 3,41 gha/preb.).

Ključne besede: trajnostni razvoj, okoljski prostor, ekološke sledi, lokalna skupnost, tipi poselitvenih območij, mestna občina Kranj

\section{SYSTEMIC ENVIRONMENTAL EVALUATION OF SUSTAINABLE DEVELOPMENT OF SETTLEMENT AREAS IN KRANJ URBAN MUNICIPALITY}

\begin{abstract}
Using the ecological footprint and the environmental space methods for measuring sustainable development, which we empirically tested on three types of geographic areas of the municipality, non-sustainable level was discovered in three geographical areas of Kranj Urban Municipality: inner city (ecological deficit 5,44 gha per capita), suburban area (ecological deficit 7,22 gha per capita) and surrounding countryside (ecological deficit 3,41 gha per capita).
\end{abstract}

Key words: sustainable development, environmental space, ecological footprint, local community, settlement type, Kranj Urban Municipality 


\section{UVOD}

Pri primerjavi uporabnosti metod ekoloških sledi (ES) in okoljskega prostora (OP) ugotovimo, da je ES mogoče uporabiti kot podlago za presojo OP opazovanega sistema (Hayward, 2006). Ne moremo pričakovati, da bodo ljudje v manjših in bolj gosto naseljenih skupnostih sprejeli nižjo stopnjo trajnostne potrošnje, kot pa ljudje v velikih in redko poseljenih skupnostih. Zato je potrebno najti drugačen način vrednotenja presežka in primanjkljaja OP (ena od možnosti so tudi ekološki prispevki in davki). Splošna načela med državami so sprejeta, nestrinjanja pa pridejo do izraza med vladami takrat, ko je treba določiti velikost razpoložljivega OP. Razvite države naj bi glede onesnaževanja v preteklosti sprejele večino odgovornosti za zmanjšanje emisij.

Podatki o velikosti ES omogočajo lokalnim oblastem, da spremljajo stanje trajnostnega razvoja v lokalni skupnosti in jim dajejo možnosti ukrepanja. ES lahko npr. pokažejo velikost porabe virov v gospodinjstvih, koliko virov je potrebno uvoziti ali izvoziti. Ker je metoda ES globalno poenotena, lahko opazovani sistem primerjamo z drugimi sistemi in ugotavljamo njegove prednosti oziroma slabosti. Podatki o velikosti ES predstavljajo dodano vrednost obstoječih zbirk podatkov o stanju okolja (okolje, gospodarstvo, socialno stanje okolja), ki so že dostopni v statističnih poročilih in jih je mogoče uporabiti za načrtovanje razvoja. Za manjše lokalne skupnosti, ki statistično niso obdelane samostojno, je te podatke treba pridobiti na ustrezen, lokalno mogoč način.

Podatki o velikosti ES lahko podajo odgovore na vprašanja ustreznosti obstoječe infrastrukture, kako načrtovati razvoj, da bo raba virov čim učinkovitejša, da bo okolje za prebivalce čim bolj zdravo. Brez primerljivih podatkov o regiji je načrtovanje trajnostnega razvoja oteženo, takšen primerljiv podatek pa so lahko ES.

Uspeh globalnega prizadevanja za trajnostni razvoj bo odvisen od uspeha na lokalni ravni, ker lahko na tak način vplivamo na $70 \%$ svetovnega prebivalstva (Footprint for cities, 2012). Poleg gostote prebivalcev v urbanem okolju ima pomembne posledice tudi širitev mesta. Urbana območja predstavljajo netipično obliko biotske pestrosti in neposredno vplivajo na kakovost vode, zemlje in zraka. Podeželska območja so prav tako pod vplivom urbanizacije. Kljub neprijaznemu in pogosto onesnaženemu okolju, ki ga mesto predstavlja, so se nekatere živali in rastline uspele prilagoditi življenjskim pogojem v mestih.

Potrebne bioproduktivne površine za oskrbo povprečnega prebivalca gospodarsko razvitih mest so bistveno večje od površin mest, kar predstavlja velik ekološki deficit (Plut, 2006). ES New Yorka in Tokia presegajo velikost mestnih površin za 100-krat, Vancouvra za 200-krat, Londona za 125-krat, 29 baltiških mest za 565-1130-krat. Mnenje strokovnjakov je, da obstoječe materialne organizacije mest razvitega sveta ni mogoče planetarno širiti oziroma trajno uporabljati (Plut, 2006).

Koncept OP nam pove, da obstaja zgornja meja izkoriščanja naravnih virov in da bi morala biti pravica do njihovega izkoriščanja enakomerno in pravično porazdeljena v razvitih državah in v državah v razvoju. Poleg zmanjšanja porabe bo treba aktivnosti usmeriti v večjo učinkovitost energijskih in snovnih tokov. V gospodarsko razvitih državah sta poraba naravnih virov in obremenjevanje okolja na prebivalca tudi do petkrat večja kot je planetarno in trajnostno sprejemljiva raven. 
Izhodišče načela pravičnosti v Towards Sustainable Europe (TSE) (Sustainable development, 2009) je, da je velikost OP izračunana na posameznika. Pri takšnem pristopu redko naseljene države nimajo več prednosti, kot je to pri metodi ES. Določitev količin trajnostne rabe posameznih naravnih virov lahko izvedemo na znanstveni oceni, ki upošteva rabo virov, če to ni mogoče, pa je potrebno izvesti presojo, ki smo jo pripravljeni sprejeti.

\section{METODOLOŠKI KONCEPT EKOLOŠKIH SLEDI IN OKOLJSKEGA PROSTORA}

Večina v prispevku predstavljenega gradiva je rezultat magistrskega dela $\mathrm{z}$ naslovom Ekološko sledenje razvoja lokalnih skupnosti (Žun, 2004), katerega mentor je bil dr. Sašo Medved, in doktorskega dela z naslovom Merjenje in vrednotenje trajnostnega razvoja lokalnih skupnosti z metodo ekoloških sledi in okoljskega prostora (Žun, 2013), ki je bilo izdelano pod mentorstvom dr. Dušana Pluta.

Kakovost življenja in razvoj človeštva temeljita na povezanosti z življenjskim prostorom, ki ga imamo na voljo. Značilnosti življenjskega prostora so:

- omogočanje pridelave hrane;

- uravnavanje procesov v ozračju in vodnem krogu;

- zagotavljanje biološke raznolikosti in nudenje življenjskega prostora flori in favni;

- shranjevanje naravnih neobnovljivih virov - goriva, mineralov, gradbenih materialov;

- omogočanje gradnje naselij, transportnih poti;

- omogočanje odlaganja odpadkov in

- ohranjanje kulturne in naravne dediščine.

Vendar površine življenjskega prostora človeštvo, posameznik ne uporablja v enakem obsegu. Zato je bila razvita teorija merjenja sonaravno trajnostnega razvoja na osnovi velikosti prostora, ki si ga 'prisvoji' opazovani sistem (človeštvo, država, lokalna skupnost, posameznik), in na katerem opazovani sistem zadovoljuje svoje življenjske in razvojne potrebe. Velikost prostora merimo s površinskimi enotami, ki jih imenujemo ekološke sledi (ES). ES predstavljajo površino življenjskega prostora (gha = globalni hektar), ki je nujna za stalno proizvodnjo virov in asimilacijo odpadkov, ki jih proizvede opazovani sistem. Metoda temelji na oceni nosilne kapacitete okolja.

Metoda je bila razvita v okviru projekta Sustainable Europe (McLaren, 2003). Leta 1992 jo je kot metodo merjenja trajnostnega razvoja uveljavila skupina Friends of Earth Netherland. Metoda se je uveljavila v globalnem merilu za sisteme na široki velikostni skali. To je posledica dveh izrazitih primerjalnih prednosti te metode: je integralni kazalec trajnostnega razvoja in, ker jih merimo s površinskimi enotami (globalni ha), so nazorno predstavljive in jih lahko izražamo z absolutnimi vrednostmi.

Glede na sistem vrednotenja snovnih in energijskih tokov v opazovanem sistemu, lahko ES določimo z:

- integralno metodo - ovrednotimo vstopajoče in notranje vire v sistemu ter izstopajoče tokove na meji sistema ali 
- $\quad$ komponentno metodo - ovrednotimo potrebe posameznikov v sistemu; vsota ES vseh posameznikov predstavlja ES celotnega opazovanega sistema.

Izračun ES temelji na naslednjih predpostavkah (McLaren, 2003):

- da je mogoče slediti snovnim in energijskim tokovom v opazovanem sistemu, vključno s količinami odpadkov, ki pri porabi in pretvorbah nastajajo;

- za večino snovi in odpadkov, ki pri njihovi uporabi nastanejo, lahko z upoštevanjem tehnologij črpanja, uporabe in odlaganja njihove količine izrazimo s površino, ki je potrebna, da so ti tokovi stalni;

- surovin, za katere ne moremo določiti toka porabe in odpadkov, ne vključujemo v izračun ES;

- da v primeru dvomov izberemo najbolj previdno oceno ES, ki nam da največjo vrednost;

- da pri izračunu ES ne upoštevamo aktivnosti ljudi, za katere trenutno ni zadovoljivih podatkov;

- pri analizah ne upoštevamo aktivnosti, ki nepopravljivo uničujejo okolje (izsuševanje vodonosnikov, golosek,... ) ali rabo snovi, ki se v okolju ne razgradijo (plutonij, PCB, CFC in druge).

Metoda okoljskega prostora (OP) je sicer podobna metodi ES, vendar nudi večje možnosti pri obravnavah na političnih ravneh, ker je pri reševanju okoljskih problemov lažje ukrepati kratkoročno po posameznih področjih. Pojem OP je prvič uvedel Horst Siebert leta 1982. Opredeljen je bil kot »skupni prostor, ki je na voljo za našo uporabo, ne da bi zmanjšali možnosti za prihodnost«. Kasneje je bila metoda posodobljena s trajnostnimi načeli (Buitenkamp, Venner, Wams, 1993; Opschoor, Weterings, 1994).

Bistvo preučevanja OP je vrednotenje virov v določenem geografskem okolju in na osnovi teh ugotovitev določiti smernice rabe teh virov. Metoda je osnovana na dveh temeljnih načelih: spoštovanju ekoloških omejitev in enakem dostopu do virov za vse.

Prvo načelo je, da je potrebno spoštovati okoljske omejitve. Tak pristop temelji na ideji, da obstajajo meje zmogljivosti planeta Zemlje za absorbiranje onesnaženja in odpadkov ter rabe naravnih virov. Meja zmogljivosti Zemlje ni mogoče določiti z absolutno natančnostjo, pogosto pa postanejo vidne šele, ko meje oziroma omejitve že presežemo. Za določitev OP je že dovolj, da so omejitve okvirno določene, tako da lahko določimo cilje. Metoda vključuje tudi načelo previdnosti, ki pravi, da nepoznavanje natančnih meja ni izgovor za neukrepanje. Trditev o omejenih zmožnostih Zemlje ne pomeni, da na svetu zmanjkuje sredstev, ampak se nanaša na izčrpavanje neobnovljivih virov in s tem zmanjševanje zalog in posledično ne-trajnostne rabe (Hille, 1997; Cohen, 2007).

Drugo načelo je načelo medgeneracijske solidarnosti, enakosti. Vsi ljudje sedanjih in prihodnjih generacij imajo enake pravice do porabe virov. Razpoložljivi OP je potrebno porazdeliti na enaki osnovi na prebivalca (Buitenkamp, Venner, Wams, 1993; Carley, Spapens, 1998; Sachs, Loske, Linz, 1998). Lastniški kapital se šteje za moralno in politično nujnost (Carley, Spapens, 1998). Omejitve porabe virov je treba uporabljati enako za vse ljudi. Neenakosti pri porabi virov lahko vodijo k političnim konfliktom. 
Na podlagi teh dveh načel ocenimo razpoložljivost vira in količino emisij ter določimo velikost OP za posamezno skupino ali geografsko enoto. Izračuni temeljijo na porabi sredstev. Za vire, ki lahko za okolje predstavljajo nepredvidljiva tveganja (npr. jedrska energija), je vrednost OP nič, kar pomeni postopno opuščanje.

Velikost OP določimo tako, da definiramo trajnostno sprejemljive snovne in energijske tokove, dobljene vrednosti delimo s številom prebivalcev in tako določimo velikost virov, ki so na voljo posamezniku.

Poleg omenjenih dveh temeljnih načel lahko upoštevamo tudi:

- načelo kakovosti življenja;

- načelo previdnosti;

- načelo bližine;

- načelo subsidiarnosti;

- načelo izkoriščanja neobnovljivih virov v zaprtem krogu.

Načelo kakovosti življenja je tretje glavno načelo OP in pomeni rabo virov, ki prispeva h kakovosti življenja. Proizvodnja in poraba materialnih dobrin prek določenega praga negativno vplivata na blaginjo ljudi, čeprav pričakujemo nasprotno. Zmanjševanje porabe ne pomeni nujno tudi slabše kakovosti življenja. Kljub temu pa je večina človeštva ujeta $\mathrm{v}$ povečevanje energijskih in snovnih tokov in tudi $\mathrm{k}$ stremljenju po povečevanju bruto domačega proizvoda (BDP). Zmanjšanje porabe virov, oziroma povečevanje izkoristkov snovnih in energijskih tokov, zato zahteva spremembo vrednostnih sistemov na ravni institucij in tudi na ravni posameznikov. Opredelitev kakovosti življenja je prepuščena skupnosti, za katero se določa OP.

Metoda OP je realnejša od metode ES, čeprav so nekateri pogledi obeh metod zelo podobni. Metodi OP in ES se razlikujeta $\mathrm{v}$ tem, da želi metoda ES prikazati kazalec z enotnim agregatnim kazalcem bioproduktivne površine (v gha). S tem enotnim kazalcem lahko ugotovimo stopnjo trajnostnega razvoja opazovanega sistema. Nasprotno pa metoda OP uporablja vrsto kazalcev za različne vire in se običajno ne prikazuje v agregatnem kazalcu. Prednost takšnega kazalca je možnost hitrega ukrepanja za doseganje konkretnih ciljev.

Metodološke razlike med obema metodama so pomembne v več pogledih:

- različne ocene uspešnosti trajnostnega razvoja lahko vplivajo na stališča, ali so obstoječi snovni in energijski tokovi na ustrezni ravni oziroma, ali jih je treba prilagoditi ciljem trajnostnega razvoja;

- metodi se razlikujeta tudi v uporabnosti določevanja političnih smernic za doseganje trajnostnega razvoja. Metoda ES je na nek način pristranska, saj imajo prednost velike, redko poseljene države in zapostavlja načelo pravičnosti dostopanja do virov za vse. Metoda ES omogoča s svojimi kazalci oblikovanje konkretnih ciljev;

- metoda ES je uporabna na različnih velikostih opazovanih sistemov (lokalna skupnost, država, planet), kar omogočajo različni pristopi (komponentna, integralna metoda). Metodo OP je mogoče učinkoviteje uporabljati na večjih, statistično bolje obdelanih sistemih. 


\section{MERJENJE TRAJNOSTNEGA RAZVOJA LOKALNE SKUP- NOSTI MO KRANJ}

Za analizo ES je potrebno izračunati velikost bioproduktivne površine. Pri njenem izračunu upoštevamo površino opazovanega sistema in število prebivalcev. Preglednica 1 prikazuje izračunano velikost bioproduktivnega prostora v MO Kranj. Ta se lahko glede na faktor pridelka spreminja, podatek pa potrebujemo za primerjavo z velikostjo ES. Velikost prostora, ki ga zasedajo posamezne vrste bioproduktivnih površin, povzamemo po uradnih statističnih virih (Statistični letopis RS 2006, 2006). Ekvivalentni faktorji predstavljajo svetovno povprečje (Wackernagel, Rees, 1996; Wackernagel in sod., 2006), medtem ko je faktor pridelka lokalnega značaja za opazovani sistem. Faktorji pridelka za Slovenijo so določeni za leto 2008 (Statistični letopis RS 2009, 2009; Matijašič, 2003) glede na količine pridelkov in svetovno povprečje.

Preglednica 1: Velikost bioproduktivnih površin na prebivalca v MO Kranj (2008) Table 1: Size of bio-productive land per capita in Kranj Urban Municipality (2008)

\begin{tabular}{|c|c|c|c|c|c|}
\hline Vrsta bioproduktivnih površin & $\begin{array}{c}\text { Površina } \\
\text { (ha) }\end{array}$ & $\begin{array}{c}\text { Površina } \\
\text { (ha/preb.) }\end{array}$ & $\begin{array}{c}\text { Ekvivalentni } \\
\text { faktor (gha/ha) }\end{array}$ & $\begin{array}{c}\text { Faktor } \\
\text { pridelka } \\
\text { (1) }\end{array}$ & $\begin{array}{c}\text { Globalni } \\
\text { hektarji } \\
\text { (gha/preb.) }\end{array}$ \\
\hline Kmetijske površine & 4560 & 0,09 & 2,11 & 1,69 & 0,31 \\
\hline Pašniki & 561 & 0,01 & 0,47 & 3,60 & 0,02 \\
\hline Gozdovi kot vir gradbenega lesa & 8205 & 0,63 & 1,35 & 2,42 & 0,52 \\
\hline $\begin{array}{l}\text { Sladkovodna območja kot vir } \\
\text { hrane }\end{array}$ & 137 & 0,01 & 0,35 & 1,00 & 0,00 \\
\hline $\begin{array}{l}\text { Pozidane površine naselij, } \\
\text { infrastrukturne površine }\end{array}$ & $1626^{*}$ & $0,03 \times 0,1 * *$ & 1,35 & 1,00 & 0,01 \\
\hline $\begin{array}{l}\text { Energijske površine kot } \\
\text { ponor toplogrednih plinov z } \\
\text { ekvivalentom } \mathrm{CO}_{2}\end{array}$ & & - & 1,00 & - & - \\
\hline $\begin{array}{l}\text { Potreben prostor za zagotavljanje } \\
\text { biotske raznolikosti*** }\end{array}$ & & & & & 0,10 \\
\hline Preostanek & & & & & 0,76 \\
\hline Skupaj & 15.089 & 0,29 & & & 0,86 \\
\hline
\end{tabular}

Vir/Source: Žun (2013)

Opombe: *Od tega 884,5 ha strnjeno mestno jedro; ${ }^{* *}$ Pri pozidanih površinah ocenjujemo, da vključujejo $10 \%$ zelenih površin (parkov); ***12\% bioproduktivne površsine namenimo zagotavljanju biotske raznolikosti.

Travnike in sadovnjake prištevamo k rodovitnim kmetijskim površinam, saj se na njih izvaja intenzivna pridelava živalske krme in se ne uporabljajo kot pašniki. 
Analiza bioproduktivne površine na prebivalca (0,86 gha/preb.) v MO Kranj potrjuje dejstvo, da gre za občino z večjo gostoto prebivalcev, saj je bioproduktivna površina na posameznika bistveno nižja od slovenskega povprečja (2,4 gha/preb.) in nižja tudi od svetovnega povprečja (1,8 gha/preb.) (Living planet report 2010, 2010). Zaradi tega bo potrebno strategije razvoja lokalne skupnosti načrtovati zelo skrbno, z izrazitim poudarkom na racionalni rabi prostora, snovi in energije. Istočasno to pomeni, da bo približevanje lokalnemu trajnostnemu razvoju pomenilo tudi približevanje globalnemu.

Izračun ES prebivalcev MO Kranj (preglednica 2) pokaže, da te znašajo 6,34 gha/prebivalca. Največji delež predstavljajo snovi in hrana, sledi neposredna raba energije, mobilnost, odpadki ter grajeno okolje. Ker bistveno presegajo lokalno bioproduktivno površino (0,76 gha/preb.) kot tudi bioproduktivno površino Slovenije (2,55 gha/preb.; Žun, 2004 ) in tudi svetovno bioproduktivno površino (1,8 gha/preb.) (Living planet report 2010, 2010), lahko ugotovimo globalno kot tudi lokalno neuravnoteženost ES. Trenutno ravnanje prebivalcev MO Kranj ne vodi niti k lokalnemu niti h globalnemu trajnostnemu razvoju. Na splošno velja, da smo še vedno v obdobju, ko ES tako lokalno kot tudi globalno naraščajo (Living planet report 2010, 2010). Takšen trend je opisan tudi v literaturi (Žun, 2004) in je posledica napačnega ravnanja z naravnimi viri, saj se vedenjski vzorec, ki vodi v netrajnostno stanje, ne spreminja.

Izrazito drugačen trend je pri bioproduktivni površini, ki se je globalno zaradi rasti števila prebivalcev in povečevanja pozidanih površin, zmanjšala s 3,7 gha/preb. v letu 1961 na 1,8 gha/preb. v letu 2007 (Living planet report 2010, 2010). V nekaterih scenarijih (Žun, 2004) je mogoče zaslediti tudi usmeritve k povečevanju bioproduktivne površine. Večina teh scenarijev ne upošteva saniranja degradiranih površin, ampak uvajanje še bolj intenzivnega kmetovanja in posledično večje hektarske donose ob uporabi umetnih gnojil in fitofarmacevtskih sredstev.

Preglednica 2: Ekološke sledi na prebivalca MO Kranj, porazdeljene po tipih bioproduktivne površine (2008)

Table 2: Ecological footprint per inhabitant of Kranj Urban Municipality, distributed by type of bio-productive area (2008)

\begin{tabular}{|l|c|c|c|c|c|c|c|}
\cline { 2 - 8 } & $\begin{array}{l}\text { Energijske } \\
\text { površine }\end{array}$ & $\begin{array}{c}\text { Kmetijske } \\
\text { površine }\end{array}$ & Pašniki & Gozdovi & $\begin{array}{c}\text { Pozidane } \\
\text { površine }\end{array}$ & $\begin{array}{c}\text { Vodne } \\
\text { površine }\end{array}$ & $\begin{array}{c}\text { Skupaj glede } \\
\text { na nastanek }\end{array}$ \\
\cline { 2 - 8 } \multicolumn{1}{l|}{ (gha/preb.) } \\
\hline $\begin{array}{l}\text { Neposredna raba } \\
\text { energije }\end{array}$ & 0,80 & & & 0,01 & 0,01 & & 0,82 \\
\hline Mobilnost & 0,56 & & & & & & 0,56 \\
\hline Hrana & 0,20 & 1,20 & 0,49 & & & & 1,89 \\
\hline Snovi & 1,25 & 0,06 & & 1,20 & 0,14 & & 2,65 \\
\hline Odpadki & 0,10 & & & & 0,19 & & 0,29 \\
\hline Grajeno okolje & & & & & 0,03 & & 0,03 \\
\hline Voda & 0,10 & & & & & & 0,10 \\
\hline Skupaj & $\mathbf{3 , 0 1}$ & $\mathbf{1 , 2 6}$ & $\mathbf{0 , 4 9}$ & $\mathbf{1 , 2 1}$ & $\mathbf{0 , 3 7}$ & & $\mathbf{6 , 3 4}$ \\
\hline
\end{tabular}

Vir/Source: Žun (2013) 
Iz primerjave ES prebivalcev MO Kranj glede na bioproduktivne površine (slika 1) je razvidno, da je največja obremenitev energijskih površin, ki so potrebne za absorbcijo toplogrednih plinov (3,01 gha/preb., 47 \%), sledijo kmetijske površine (1,26 gha/preb., $20 \%$ ) in gozdovi (1,21 gha/preb., $19 \%$ ). Za gozdne površine tudi na območju MO Kranj velja, da niso izkoriščene v tolikšni meri, kot dopušča trajnostno gospodarjenje. V posebni skupini sta kategoriji pašniki $(0,49$ gha/preb., $8 \%)$ in pozidane površine $(0,37 \mathrm{gha} /$ preb., $6 \%$ ) (slika 1). Pri pozidanih površinah se izkaže, da večji del obremenitve predstavljajo uvožene ES. Te obremenitve nastajajo drugje, vendar jih pripišemo uporabniku po načelu 'onesnaževalec plača', torej prebivalcem MO Kranj.

Slika 1: Sestava ES prebivalcev MO Kranj po tipih bioproduktivne površine (2008) Figure 1: The composition of the ecological footprint of residents of Kranj Urban Municipality by type of bio-productive land (2008)

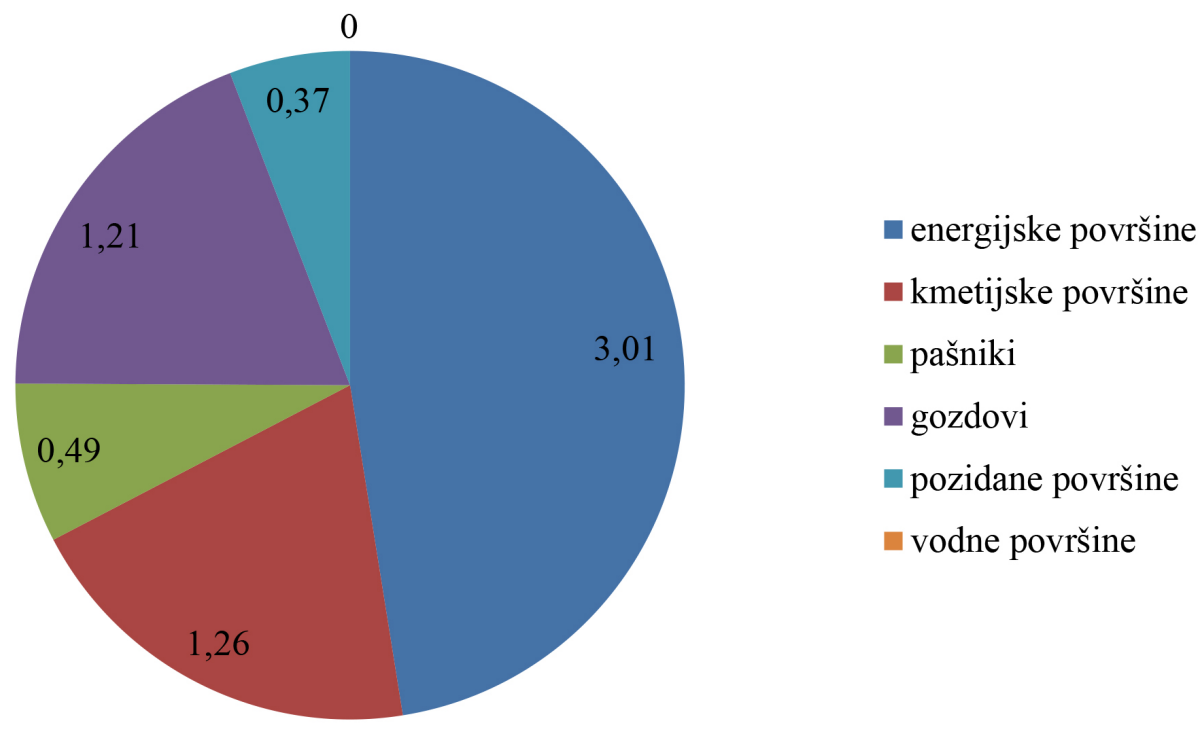

Vir/Source: Žun (2013)

Pri primerjavi ES prebivalcev MO Kranj glede na izvor obremenitve je razvidno (slika 2), da je največja obremenitev zaradi rabe snovi (2,65 gha/preb., $42 \%)$, sledi hrana (1,89 gha/preb., $30 \%$ ), ki kljub drugačnim napovedim v preteklosti narašča (Žun, 2004). Sledita neposredna raba energije $(0,82$ gha/preb., $13 \%)$ in mobilnost $(0,56$ gha/preb., $9 \%$ ). Ločeno od snovi smo obravnavali odpadke $(0,29$ gha/preb., $5 \%)$, v zadnji skupini pa so grajeno okolje ( 0,03 gha/preb.) in vodne površine $(0,1$ gha/preb., $2 \%)$.

Za nadaljno analizo ES prebivalcev MO Kranj po poselitvenih območjih je bilo potrebno najprej določiti njihove meje. Določitev tipov poselitvenih območij in podeželja je večkrat zelo težavno, saj obstaja veliko definicij, ki se med seboj razlikujejo glede na namen raziskave ter glede na potrebe po primerljivosti podatkov. 
Slika 2: Sestava ES prebivalcev MO Kranj glede na vir nastanka (2008)

Figure 2: The composition of the ecological footprint of residents of Kranj Urban Municipality by source (2008)

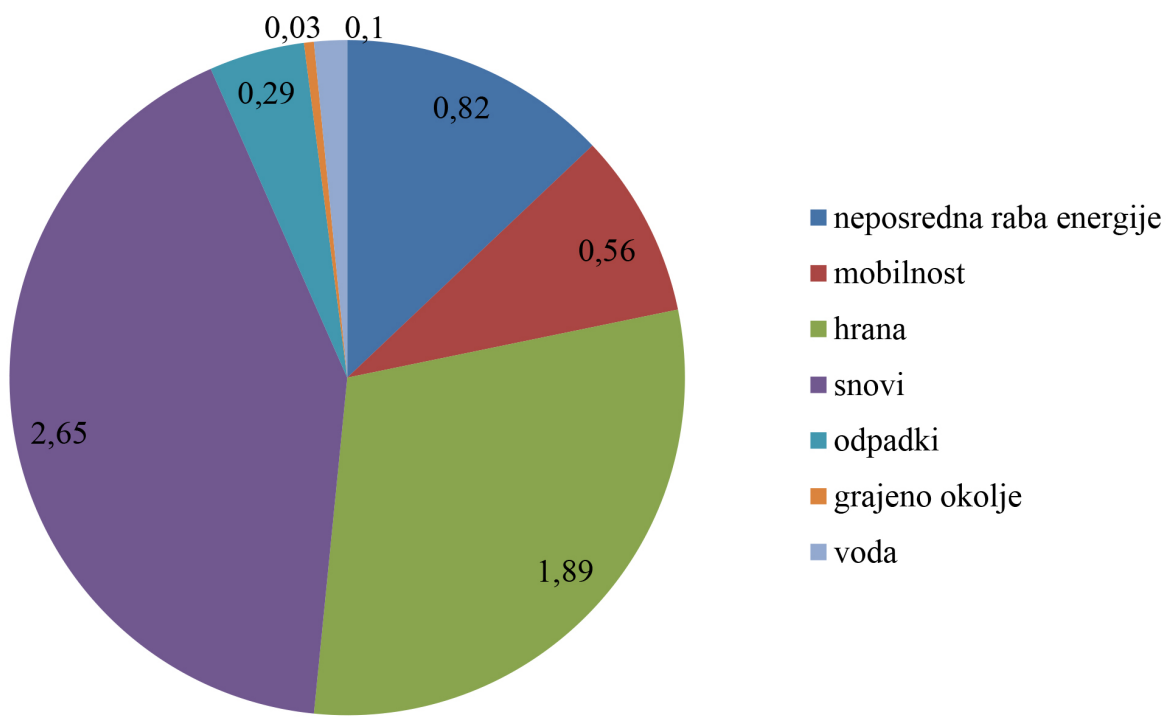

Vir/Source: Žun (2013)

Evropska statistika uporablja za teritorialno členitev mestnih in podeželskih območij definicijo OECD (Rural development in the European Union - Statistical and economic information - Report 2006, 2006), Statistični urad Evropskih skupnosti (Eurostat) pa je predlagal členitev po stopnji urbanizacije. Obe členitvi temeljita na gostoti poseljenosti, oziroma deležu prebivalstva, ki živi na podeželskih območjih, medtem ko socialno-ekonomska merila niso upoštevana. V nadaljevanju se bomo pri delitvi na tipe geografskih območij MO Kranj poskušali čim bolj približati omenjenim merilom.

Ključni kriterij za določitev podeželskih območij po OECD na lokalni ravni je gostota prebivalstva (Erhart, 2007). Meja med mestnimi in podeželskimi območji je na lokalni ravni določena pri gostoti poselitve $150 \mathrm{preb} . / \mathrm{km}^{2}$. Metodologija OECD je mednarodno sprejeta klasifikacija podeželja, zato jo bomo v tem delu uporabili kot izhodišče za določitev geografskih območij MO Kranj (Rural development in the European Union - Statistical and economic information - Report 2006, 2006).

Koncept stopnje urbanizacije, ki jo je zasnoval Eurostat, bomo delno uporabili kot pomoč pri določitvi suburbaniziranih območij (Erhart, 2007). Ta koncept vsebuje tri kriterije: gostoto poselitve, teritorialno povezanost lokalnih enot in minimalno število prebivalcev.

Pri interpretaciji deleža ozemlja, ki ga uvrščamo v posamezni tip območij, upoštevamo, da po ocenah zazidljiva območja predstavljajo 3,1 \% celotnega ozemlja Slovenije, intenzivna kmetijska raba pa 20,5 \% (Kokalj, Oštir, 2005). Podeželski prostor v Sloveniji 
ni homogen in je podvržen razvojnim procesom z različno intenzivnostjo. Različnost je pogojena z geografskimi značilnostmi in izhaja iz naravnih, zgodovinskih, družbenih in gospodarskih procesov, kar je razlog za nastanek mnogih členitev, katerih metodologije pogosto niso primerljive. Zato bomo posamezna merila prilagodili našim potrebam. Glede na opisano metodologijo smo krajevne skupnosti MO Kranj razdelili na naslednje tri tipe geografskih območij (slika 3, preglednica 3):

- strnjeno mestno jedro: Bratov Smuk, Center, Čirče, Huje, Planina, Vodovodni Stolp, Zlato Polje;

- suburbanizirano območje: Britof, Golnik, Gorenja Sava, Kokrica, Orehek-Drulovka, Predoslje, Primskovo, Stražišče, Struževo, Tenetiše;

- podeželje: Besnica, Bitnje, Hrastje, Jošt, Mavčiče, Podblica, Trstenik, Žabnica.

Osnovne podatke o krajevnih skupnostih (preglednica 3) smo povzeli iz različnih virov, in sicer za število prebivalcev in število gospodinjstev iz podatkov popisa 2002 (Rezultati Popisa 2002, 2014), površino krajevnih skupnosti pa iz podatkov Območne geodetske uprave Izpostava Kranj.

Slika 3: Tipi poselitvenih območij v MO Kranj

Figure 3: Types of settlement areas in Kranj Urban Municipality

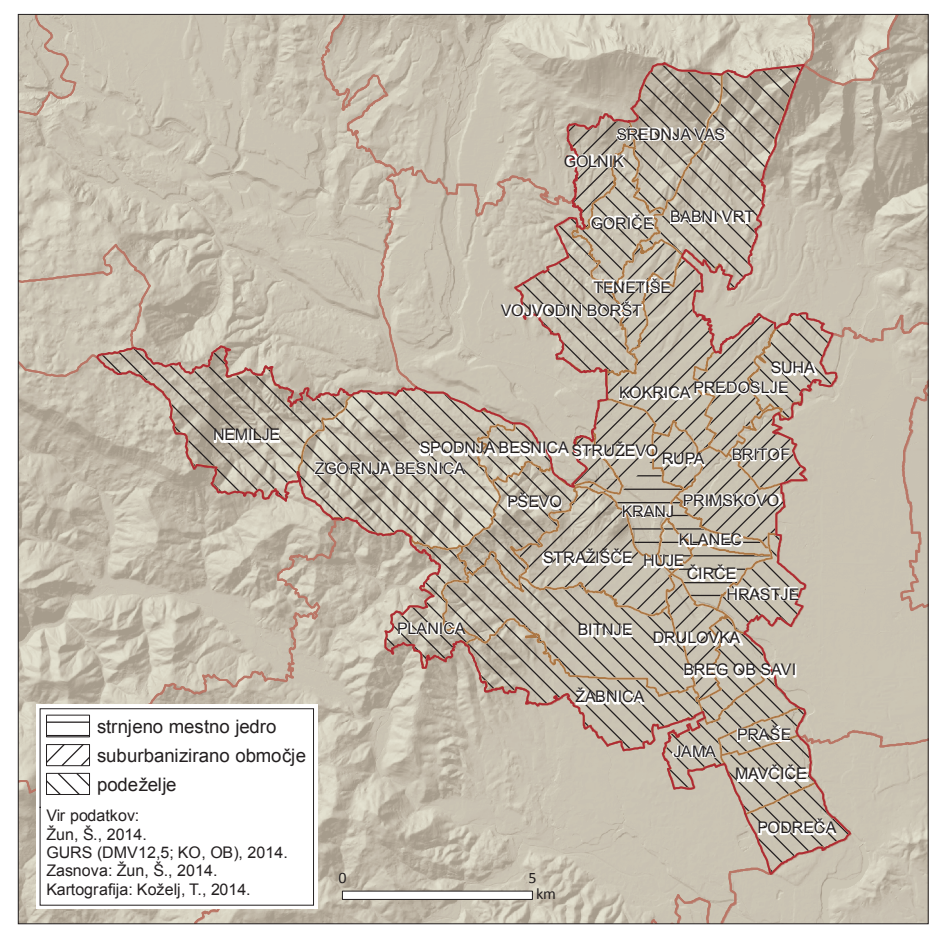

Vira/Sources: Območna geodetska uprava, Izpostava Kranj-izpis površin (stanje 1. 1. 2003); Mestna občina Kranj: http://gis.iobcina.si/gisapp/Default.aspx?a=kranj 
Preglednica 3: Tipi poselitvenih območij v MO Kranj

Table 3: Types of settlement areas in Kranj Urban Municipality

\begin{tabular}{|l|c|c|c|c|c|c|c|}
\hline MO Kranj & $\begin{array}{c}\text { Število } \\
\text { preb. } \\
\text { (2008) }\end{array}$ & $\begin{array}{c}\text { Površina } \\
\text { (ha) }\end{array}$ & $\mathbf{\%}$ & $\begin{array}{c}\text { Število } \\
\text { gospodinjstev } \\
\text { (2008) }\end{array}$ & \% & $\begin{array}{c}\text { Gostota } \\
\text { (preb./km²) }\end{array}$ \\
\hline $\begin{array}{l}\text { Strnjeno mestno } \\
\text { jedro }\end{array}$ & 22.280 & 42,6 & 884,5 & 5,9 & 8493 & 45,8 & 2519 \\
\hline $\begin{array}{l}\text { Suburbanizirano } \\
\text { območje }\end{array}$ & 21.175 & 40,5 & 4625,7 & 30,7 & 7177 & 38,7 & 458 \\
\hline Podeželje & 8810 & 16,9 & 9579,7 & 63,5 & 2858 & 15,4 & 91 \\
\hline Skupaj & $\mathbf{5 2 . 2 6 5}$ & $\mathbf{1 0 0}$ & $\mathbf{1 5 . 0 8 9 , 9}$ & $\mathbf{1 0 0}$ & $\mathbf{1 8 . 5 2 8}$ & $\mathbf{1 0 0}$ & $\mathbf{3 4 6}$ \\
\hline
\end{tabular}

Vir/Source: Žun (2013)

Pri analizi ES prebivalcev MO Kranj po tipih poselitvenih območij (preglednica 4, slika 4) ugotavljamo, da imajo prebivalci suburbaniziranega območja največje ES na področju neposredne rabe energije, porabe snovi in odpadkov. Na področju porabe hrane sta si podeželje in suburbanizirano območje enaka. Prebivalci strnjenega mestnega jedra imajo najmanjše ES na vseh področjih, razen na področju neposredne rabe energije, kjer imajo prebivalci podeželja najbolj trajnosten vzorec neposredne rabe energije. Prebivalci podeželja imajo največje ES na področju mobilnosti, kar je povezano tudi z vedenjskim vzorcem in zgostitvijo storitvenih dejavnosti in javnih služb v urbanem središču. Ugotovili smo tudi nepričakovano visoke vrednosti ES pri porabi hrane in snovi v vseh poselitvenih tipih. V celoti pa so bile ES na prebivalca v MO Kranj največje v suburbaniziranih območjih, sledilo je podeželje, najmanjše pa so bile v strnjenem mestnem jedru Kranja.

Preglednica 4: ES prebivalcev MO Kranj po nastanku in tipih poselitvenih območij (ghal preb.; 2008)

Table 4: Ecological footprint of inhabitants of Kranj Urban Municipality by origin and types of settlements (gha per capita; 2008)

\begin{tabular}{|l|c|c|c|c|}
\cline { 2 - 5 } \multicolumn{1}{c|}{} & MO Kranj & $\begin{array}{c}\text { Strnjeno } \\
\text { mestno jedro }\end{array}$ & Suburbanizirano območje & Podeželje \\
\hline Neposredna raba energije & 0,81 & 0,87 & 1,05 & 0,38 \\
\hline Mobilnost & 0,56 & 0,29 & 0,54 & 0,84 \\
\hline Hrana & 1,89 & 1,62 & 1,93 & 1,93 \\
\hline Snovi & 2,65 & 2,28 & 3,71 & 2,99 \\
\hline Odpadki & 0,29 & 0,25 & 0,40 & 0,33 \\
\hline Grajeno okolje & 0,03 & 0,03 & 0,03 & 0,03 \\
\hline Voda & 0,10 & 0,10 & 0,10 & 0,10 \\
\hline Skupaj & $\mathbf{6 , 3 4}$ & $\mathbf{5 , 4 4}$ & $\mathbf{7 , 7 6}$ & $\mathbf{6 , 6 0}$ \\
\hline
\end{tabular}

Vir/Source: Žun (2013) 
Slika 4: ES prebivalcev MO Kranj po nastanku in tipih poselitve (gha/preb.; 2008) Figure 4: Ecological footprint of inhabitants of Kranj Urban Municipality by origin and types of settlements (gha per capita; 2008)
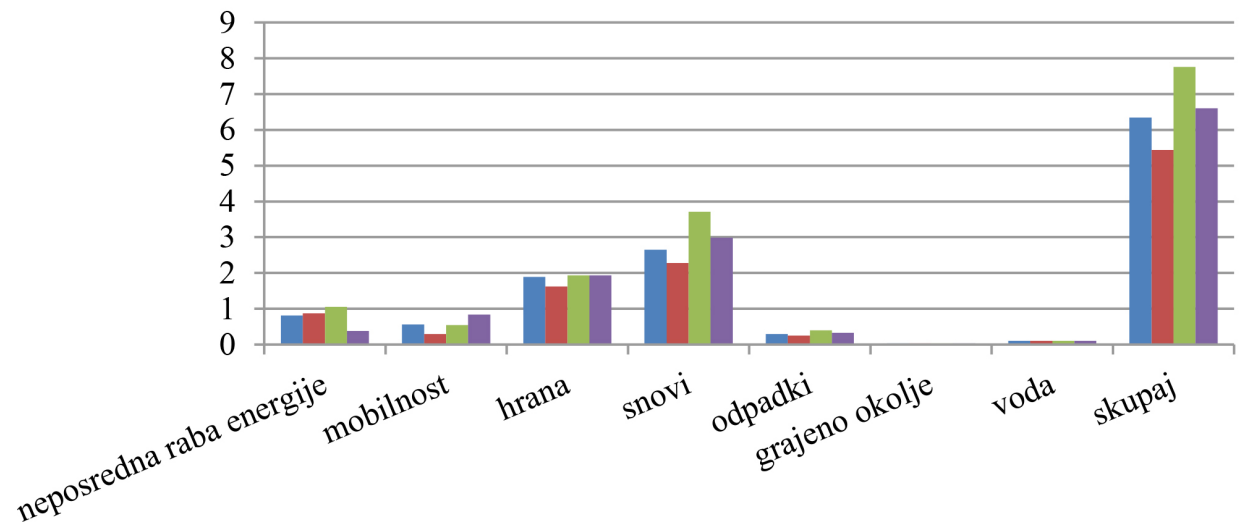

-MO Kranj $\square$ strnjeno mestno jedro $\square$ suburbanizirano območje $\quad$ podeželje

Vir/Source: Žun (2013)

Značilnosti strnjenega mestnega jedra, ki vplivajo na velikost in značilnosti ES, so:

- $\quad$ v strnjenem mestnem jedru živi $43 \%$ prebivalcev MO Kranj;

- strnjeno mestno jedro obsega $6 \%$ površine MO Kranj;

- površino strnjenega mestnega jedra prištevamo k pozidanim površinam (884,5 ha);

- življenjska raven prebivalcev mestnega jedra znaša 86 \% glede na povprečno stanje prebivalcev MO Kranj;

- bioproduktivna površina strnjenega mestnega jedra znaša 0,005 gha/preb.;

- ekološki primanjkljaj strnjenega mestnega jedra znaša 5,435 gha/preb.

Značilnosti suburbaniziranega območja, ki vplivajo na velikost in značilnosti ES, so:

- v suburbaniziranem območju živi $41 \%$ vseh prebivalcev MO Kranj;

- suburbanizirano območje obsega $31 \%$ površine MO Kranj;

- suburbanizirano območje vključuje 741,5 ha pozidanih površin;

- življenjska raven prebivalcev suburbaniziranega območja znaša 140 \% glede na povprečno stanje prebivalcev MO Kranj;

- bioproduktivna površina suburbaniziranega območja znaša 0,543 gha/preb.;

- ekološki primanjkljaj znaša 7,217 gha/preb.

Značilnosti podeželja, ki vplivajo na velikost in značilnosti ES, so:

- na podeželju živi $16 \%$ vseh prebivalcev MO Kranj;

- podeželje obsega $63 \%$ površine MO Kranj;

- Življenjska raven prebivalcev podeželja znaša 113 \% glede na povprečno stanje prebivalcev MO Kranj; 
- $\quad$ bioproduktivna površina podeželja znaša 3,191 gha/preb.;

- $\quad$ ekološki primanjkljaj podeželja znaša 3,029 gha/preb.

Metoda ES za vrednotenje trajnostnega razvoja prebivalcev MO Kranj poda dovolj kakovostno oceno trajnostnega razvoja (preglednica 5, slika 5). Pomanjkljivost metode se pokaže pri načrtovanju prihodnjih smeri prostorskega razvoja.

Preglednica 5: Primerjava velikosti bioproduktivne površine, ES in ekološkega primanjkljaja med poselitvenimi območji v MO Kranj (2008)

Table 5: Comparison of bio-productive area, ecological footprint and ecological deficit between settlement areas in the Kranj Urban Municipality (2008)

\begin{tabular}{|l|c|c|c|}
\cline { 2 - 4 } \multicolumn{1}{c|}{} & $\begin{array}{c}\text { Bioproduktivna } \\
\text { površina (gha/preb.) }\end{array}$ & $\begin{array}{c}\text { Ekološke sledi (gha/ } \\
\text { preb.) }\end{array}$ & $\begin{array}{c}\text { Ekološki primanjkljaj } \\
\text { (gha/preb.) }\end{array}$ \\
\hline Strnjeno mestno jedro & 0,005 & 5,440 & 5,435 \\
\hline Suburbanizirano območje & 0,543 & 7,760 & 7,217 \\
\hline Podeželje & 3,191 & 6,600 & 3,409 \\
\hline MO Kranj & $\mathbf{0 , 7 6 0}$ & $\mathbf{6 , 3 4 0}$ & $\mathbf{5 , 5 8 0}$ \\
\hline
\end{tabular}

Vir/Source: Žun (2013)

Slika 5: Primerjava velikosti bioproduktivne površine, ES in ekološkega primanjkljaja med poselitvenimi območji v MO Kranj (gha/prebivalca; 2008)

Figure 5: Comparison of the size of bio-productive area, ecological footprint and ecological deficit between settlement areas in the Kranj Urban Municipality (gha per capita; 2008)

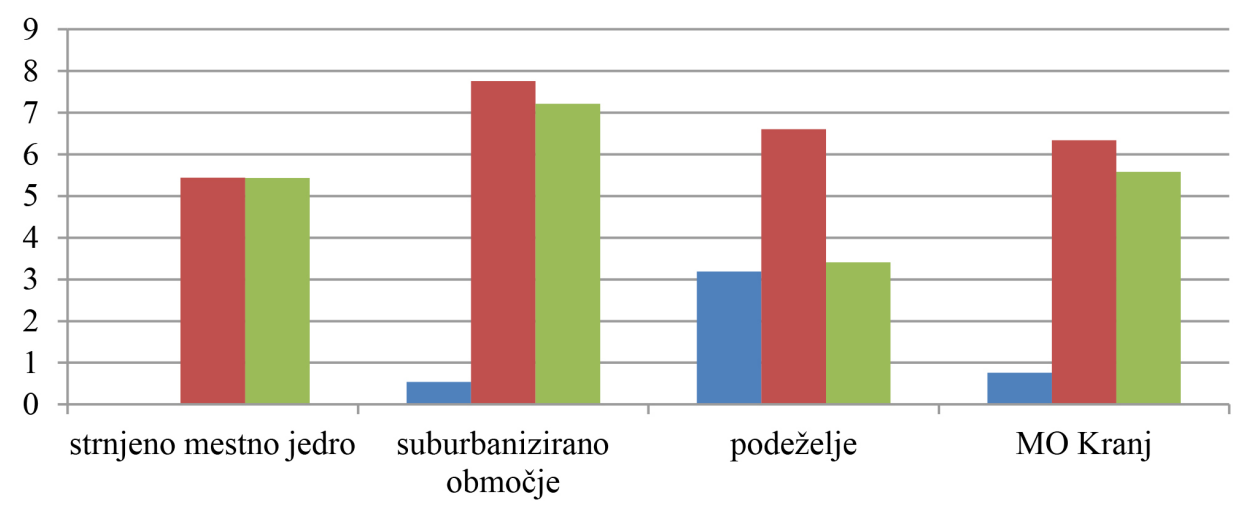

— bioproduktivna površina (gha/preb.) — ekološke sledi (gha/preb.)

- ekološki primankljaj (gha/preb.)

Vir/Source: Žun (2013) 
Primerjava razpoložljivih podatkov kaže velik ekološki primanjkljaj v mestnih občinah, predvsem zaradi majhne bioproduktivnosti površin in tudi velike gostote poselitve. Pri primerjavi bioproduktivnosti med MO Kranj in MO Ljubljana lahko ugotovimo, da je bioproduktivnost v MO Ljubljana 3,76-krat manjša od MO Kranj (Medved, 2009). Vzorec netrajnostnega razvoja ugotovimo tudi na suburbaniziranem območju MO Kranj. Na redkeje naseljenih območjih z relativno veliko površino kmetijskih zemljišč (npr. v občini Ormož) je ekološki primanjkljaj manjši v primerjavi z mestnimi občinami in tudi v primerjavi s celotno Slovenijo (Rozman, 2008). Rezultat za občino Naklo (Žun, 2004), ki prav tako kaže na velik ekološki primanjkljaj, povezujemo tudi z razdrobljenostjo in s tem s slabšo funkcionalnostjo majhnih, novonastalih občin v Sloveniji.

Glede na navedene primerjave lahko zaključimo, da je po rezultatih metode ES trajnostno najbolj sprejemljiv tip poselitve strnjeno mestno jedro s podeželjem in neizrazitim suburbaniziranim območjem. Dejavnosti, ki na suburbaniziranem območju povzročajo netrajnostno rabo prostora in virov (poselitev, infrastruktura, včasih tudi srednješolska središča, daljinsko ogrevanje), bi morali trajnostno načrtovati in po možnosti vključevati v strnjeno mestno jedro (šolska središča) ter načrtovati trajnostne tipe poselitve.

Za izračun OP (okoljskega prostora) potrebujemo konkretne podatke za snovne in energijske tokove. Težava nastane, kadar teh podatkov, izraženih v fizikalnih enotah, ni ali jih je težko dobiti. Finančni podatki, tako posamični kot agregatni, so lažje sledljivi kot snovni tokovi. Popolnejši podatki so z začetka in ne s konca življenjskega cikla izdelka. Zaradi teh dejstev je bilo mogoče na osnovi razpoložljivih podatkov na regionalni in lokalni ravni izvesti le predhodno okvirno oceno OP za MO Kranj. Treba je izvajati stalen monitoring sistema na osnovi kazalcev OP, zato je potrebno razviti poseben sistem obvladljivega sledenja snovnim in energijskim tokovom. Bolj dostopni so podatki o energijskih tokovih, snovne tokove je treba vrednotiti na osnovi podatkov, ki so dostopni večinoma samo na državni ravni ter podatkov lokalnih zbornic in združenj. Snovni tokovi cementa, jeklenih izdelkov, aluminija in klora so bili ocenjeni na osnovi podatkov, zbranih na državni ravni, in tudi prek podatkov o porabi in proizvodnji na lokalni ravni.

Ocenjuje se, da surovine, ki vstopajo v socialno-ekonomske sisteme prek potrošniških dobrin, predstavljajo zelo majhen delež, le okoli $5 \%$, ostalo vstopa v te sisteme v obliki industrijskih snovnih tokov (Wissenburg, 2006). Vendar zaradi odpadkov, ki jih te potrošniške dobrine povzročajo, teh tokov ne smemo zanemariti. Lažje je oceniti domačo porabo in rabo zemljišč prek sistemov vrednotenja rabe prostora. Razpoložljivost vodnih virov smo ocenjevali na osnovi meteoroloških podatkov o padavinah.

Zaradi pomanjkanja podatkov je treba za nadaljnjo obdelavo razvijati nove metode zbiranja podatkov v ustrezni obliki, tako na lokalni kot na regionalni ravni. Upoštevati je treba proizvodnjo in porabo na različnih ravneh s povezavo podatkov o uvozu in izvozu ter slediti zapletenim snovnim tokovom. Na osnovi podatkov, ki jih pridobimo s pomočjo geografskih informacijskih sistemov, lahko ovrednotimo podatke o naravnih virih in jih primerjamo z referenčnimi trajnostnimi vrednostmi. Na drugih področjih, npr. 
pri potrošnji blaga, je potrebno vzpostaviti pretok informacij med vsemi vpletenimi in na tak način pridobiti ustrezne agregatne kazalce.

Predhodna okvirna ocena OP v MO Kranj (preglednica 6) je izračunana na podlagi opisanega pristopa in razpoložljivih regionalnih podatkov. Manjkajoče podatke smo pridobili tako, da smo državne podatke preračunali na stanje v MO Kranj.

Preglednica 6: Vrednosti okoljskega prostora MO Kranj (2008)

Table 6: Values of the environmental space for Kranj Urban Municipality (2008)

\begin{tabular}{|l|l|}
\hline Kazalec OP & Vrednost kazalca \\
\hline Emisije $\mathrm{CO}_{2}$ & $12,25 \mathrm{t} /$ leto/preb. \\
\hline Cement & $776 \mathrm{~kg} /$ leto/preb. \\
\hline Jeklo & $497 \mathrm{~kg} /$ leto/preb. \\
\hline Aluminij & $8,8 \mathrm{~kg} /$ leto/preb. \\
\hline Klor & $8 \mathrm{~kg} /$ leto/preb. \\
\hline Zavarovane površine & $0,06 \mathrm{ha} /$ preb. $(19,4 \%$ od 2927 ha) \\
\hline Pozidane površine & $0,03 \mathrm{ha} /$ preb. $(10,8 \%$ od $1626 \mathrm{ha})$ \\
\hline Neto potreba po površini & 111.800 ha $(2,15$ ha/preb.) \\
\hline Les & $1,14 \mathrm{~m} 3 /$ preb. \\
\hline Voda & $187 \mathrm{~m}^{3} /$ preb. \\
\hline
\end{tabular}

Vir/Source: Žun (2013)

Oceno OP lokalne skupnosti MO Kranj smo primerjali s povprečnimi vrednostmi podatkov, objavljenimi v literaturi (preglednica 7), saj lahko s takšnim primerjanjem pripravljamo scenarije za trajnostni razvoj lokalne skupnosti. Pri primerjavi kazalcev OP smo ugotovili naslednje:

- visoke vrednosti OP v MO Kranj so v energetskem sektorju in so nad povprečjem EU;

- nadpovprečne vrednosti OP za cement;

- izredno visoke vrednosti OP za jeklene proizvode;

- nizke vrednosti OP za aluminij;

- nizke vrednosti OP za klor;

- razmeroma uravnotežene vrednosti OP za rabo zemljišč;

- visoke vrednosti OP za les in

- glede na porabo vode, visoke vrednosti OP za vodo. 
Preglednica 7: Primerjava vrednosti OP za MO Kranj s Toskano (Italija) in povprečjem EU (Mastino in sod., 2004; Buitenkamp, Venner, Wams, 1993)

Table 7: Comparison of values of environmental space between Kranj Urban Municipality, Tuscany (Italy), and the average of the EU (Mastino et al., 2004; Buitenkamp, Venner, Wams, 1993)

\begin{tabular}{|c|c|c|c|c|c|c|}
\hline Kazalec OP & Enota & $\begin{array}{c}\text { Toskana } \\
(2000)\end{array}$ & $\begin{array}{l}\text { Italija } \\
(2000)\end{array}$ & EU (2000) & $\begin{array}{c}\text { Slovenija } \\
(2008)\end{array}$ & $\begin{array}{c}\text { MO Kranj } \\
\text { (2008) }\end{array}$ \\
\hline Emisije $\mathrm{CO}_{2}$ & t/leto/preb. & 9,30 & 8,30 & 8,80 & 11,78 & 12,25 \\
\hline Cement & $\mathrm{kg} /$ leto/preb. & 549 & 760 & 510 & 357 & 776 \\
\hline Jeklo & kg/leto/preb. & 215 & 231 & 250 & 478 & 497 \\
\hline Aluminij & $\mathrm{kg} / \mathrm{leto} / \mathrm{preb}$. & 19 & 28 & 22 & 8,5 & 8,8 \\
\hline Klor & kg/leto/preb. & 28 & 18 & 23 & 7,7 & 8 \\
\hline Zavarovane površine & ha/preb. & 0,044 & 0,058 & 0,040 & 0,130 & 0,060 \\
\hline Pozidane površine & ha/preb. & 0,024 & 0,037 & 0,053 & 0,025 & 0,030 \\
\hline Neto potreba po površini & ha/preb. & 0,150 & & 0,039 & 0,500 & 2,150 \\
\hline Les & $\mathrm{m}^{3} /$ preb. & 0,707 & 0,540 & 0,660 & 1,090 & 1,140 \\
\hline Voda & $\mathrm{m}^{3} /$ preb. & 420 & 934 & 580 & 179 & 187 \\
\hline
\end{tabular}

Vir/Source: Žun (2013)

Ugotovimo lahko, da je treba zmanjšati rabo virov, zlasti energije in klora (Mastino in sod., 2004; McLaren, 2003; The concept of the environmental space ..., 2011). Zmanjšanje porabe naravnih virov naj bo rezultat učinkovitejše rabe in posledično zmanjšanje količine odpadkov in povečanje recikliranja. S čim boljšim izkoristkom lokalnih virov bi prav tako lahko zmanjšali transportne poti.

Ocena velikosti OP kaže potrebo po razvoju trajnostnih politik učinkovitejše rabe energije in snovnih tokov s ciljem zmanjšanja pritiskov na okolje za štirikrat v srednjeročnem obdobju in za desetkrat v dolgoročnem obdobju. Usmerjali naj bi se v zaprte kroge proizvodnje in porabe ter uvajali učinkovite gospodarske sisteme, vse to pa bi pripomoglo k višji kakovosti življenja in k manjši porabi snovi.

Analizo OP prebivalcev MO Kranj glede na poselitvena območja smo naredili v okviru možnosti, ki jih dopušča posamezno poselitveno območje.

Raba energije (emisije $\mathrm{CO}_{2}$ ) se med poselitvenimi območji razlikuje predvsem po naslednjih možnostih:

- več transportnih poti med urbanim središčem in podeželjem;

- možnost cenovno privlačnega javnega mestnega prevoza v strnjenem mestnem jedru in s posameznimi deli suburbaniziranega območja;

- možnost daljinskega ogrevanja v nekaterih delih strnjenega mestnega jedra;

- možnost preureditev večjih kotlovnic na lesno biomaso;

- večja izraba lesne biomase za ogrevanje na podeželju;

- problem energetske učinkovitosti stavb v zasebni lasti na suburbaniziranem območju;

- problem energetske učinkovitosti stavb v javni lasti v strnjenem mestnem jedru;

- na suburbaniziranem območju se načrtuje plinifikacija. 
Porabo cementa lahko razdelimo po naslednjih segmentih:

- na podeželju se gradi več individualnih objektov za potrebe kmetijstva in tudi javne infrastrukture, predvsem ceste;

- na suburbaniziranem območju se v primerjavi s podeželjem gradi manj javnih cest, manj gospodarskih objektov, več obrtnih delavnic in več individualnih hiš;

- v strnjenem mestnem jedru se gradi največ javnih objektov, komunalne infrastrukture, stanovanj, poslovnih objektov in trgovskih središč.

Poraba cementa je v strnjenem mestnem jedru v primerjavi z ostalima območjema poselitve največja, vendar je na tem območju izkoristek gradenj največji, tako z energijskega kot tudi s prostorskega stališča. Razliko v porabi jeklenih izdelkov bi lahko po vrstah poselitvenih območij razdelili po porabi v gradbeništvu in industriji. Industrija je v veliki večini skoncentrirana na suburbaniziranem območju, na levem in desnem bregu Save od Gorenje Save do Zarice. Pri porabi aluminija je podobno kot pri jeklenih izdelkih. Ne moremo pa razdeliti porabe izdelkov za enkratno uporabo po poselitvenih območjih, saj je poraba odvisna od posameznikov in ne od lastnosti poselitvenih območij. V MO Kranj je največja poraba klora v kmetijstvu, torej na območju podeželja.

Zavarovana območja so večinoma na podeželju in predstavljajo 19,4 \% celotne površine MO Kranj. Mestno jedro vključuje v svojo urbanistično strukturo strme konglomeratne stene ter vodne in obvodne habitate, saj leži med reko Savo in Kokro. Kanjon Kokre je naravna znamenitost zaradi nastanka, značilnih površinskih procesov, pestrega živalstva in rastlinstva v reki in ob njej. Kljub osrednji ravninski in prometno-gospodarsko obremenjeni legi, je v MO Kranj precejšen delež zavarovanih območij narave, varovanih gozdov in območij NATURA 2000 (Poročilo o stanju okolja v MO Kranj, 2007).

Pozidana zemljišča obsegajo 1626 ha, kar je 10,78 \% celotne površine mestne občine, oziroma $0,03 \mathrm{ha} /$ prebivalca. Med pozidane površine prištevamo tudi parke in vrtove; pri vrednotenju ES smo pri določitvi bioproduktivnosti upoštevali, da je med pozidanimi površinami $10 \%$ parkov in vrtov. Mesto Kranj se je v zadnjih desetletjih zaradi naravnih razmer in občinske urbanistične politike najbolj razširilo proti vzhodu, kjer je nastalo veliko območje stanovanjskih blokov Planina I, II, III ter nakupovalna središča na Primskovem. Na območju Planina-jug je nastalo novo trgovsko središče in stanovanjski objekti, na severnem delu pa se je gradnja nadaljevala v sklopu šolsko-športnega središča (osnovna šola, srednje šole, osnovna šola z prilagojenim programom, fakulteta).

Kazalec neto potrebe po zemljiščih smo ocenili po metodi ES. Glede na ekološki primanjkljaj 5,58 gha/preb. ocenjujemo, da je neto primanjkljaj 2,15 ha/preb. (40 \% ekološkega primanjkljaja). Porabe lesa za različne namene v industriji ne moremo razdeliti po poselitvenih območjih, saj lesnopredelovalne industrije v MO Kranj ni. Po poseku lesa na območju MO Kranj je težava enaka kot v celotni Sloveniji, saj se veliko nepredelanega lesa izvozi.

Količino razpoložljivih vodnih virov v MO Kranj, ki so v uporabi in večinoma na podeželju, smo ocenili na osnovi podatkov podjetja Komunala Kranj d.o.o. na 308 1/s, kar je $187 \mathrm{~m}^{3} /$ preb./leto. V primerjavi z mestnim prebivalstvom je poraba pitne vode $\mathrm{v}$ obmestnih naseljih večja zaradi vedenjskih vzorcev prebivalcev (npr. zalivanje zelenic). Individualna 
gradnja ima hkrati tudi velike možnosti za zbiranje in uporabo deževnice. Pregled izdatnosti obstoječih vodnih virov pokaže na veliko (zadostno) izdatnost vodnih virov na območju MO Kranj in da ni potrebe po povečevanju izkoriščanja teh virov. To in iskanje novih virov je napačen netrajnostni pristop, aktivnosti je treba usmeriti k trajnostni rabi vodnih virov, predvsem k zmanjševanju in učinkovitejši rabi načrpane vode.

\section{OCENA NAPOVEDI EKOLOŠKIH SLEDI IN OKOLJSKEGA PROSTORA MO KRANJ PO TRAJNOSTNEM SCENARIJU}

Z oceno napovedi prihodnjih pritiskov na okolje želimo ugotoviti, kako bodo različni ukrepi vplivali na zmanjšanje ES in OP po scenariju nadaljevanja količinske rasti v letih 2008, 2020 in 2050. Gre za ukrepe, ki jih zasledimo v razvojnih dokumentih EU in Slovenije ter v strokovni literaturi (preglednice 8, 9 in10) (Medved, 2006; Žun, 2004; Dawkins in sod., 2008).

Preglednica 8: Pričakovane ES prebivalcev MO Kranj glede na predvidene ukrepe in scenarij nadaljevanja količinske rasti

Table 8: Expected ecological footprint of inhabitants of Kranj Urban Municipality depending on the envisaged measures and the continuation of quantitative growth scenario

\begin{tabular}{|c|c|c|c|c|c|c|}
\hline & 2008 & 2020 & 2050 & 2020 & 2050 & \begin{tabular}{|c|}
$\begin{array}{c}\text { Velikost bio- } \\
\text { produktivnih } \\
\text { površin }\end{array}$ \\
\end{tabular} \\
\hline & & \multicolumn{2}{|c|}{ Upoštevani ukrepi } & \multicolumn{2}{|c|}{ Nadaljevanje količinske rasti } & \\
\hline Ekološke sledi & \multicolumn{5}{|c|}{ gha/prebivalca/leto } & gha/preb. \\
\hline MO Kranj & 6,34 & 5,467 & 4,121 & 9,61 & 24,77 & 0,760 \\
\hline Strnjeno mestno jedro & 5,44 & 5,033 & 3,462 & 8,51 & 22,05 & 0,005 \\
\hline Suburbanizirano območje & 7,66 & 6,752 & 5,250 & 11,72 & 29,80 & 0,543 \\
\hline \begin{tabular}{|l|} 
Podeželje \\
\end{tabular} & 6,60 & 5,142 & 4,612 & 9,74 & 25,75 & 3,191 \\
\hline Svet & 2,70 & & & & & 1,800 \\
\hline \multicolumn{7}{|l|}{ Okoljski prostor } \\
\hline \multicolumn{7}{|l|}{ MO Kranj } \\
\hline Emisije $\mathrm{CO}_{2}$ (t/leto/preb.) & 12,25 & 5,4 & 1,7 & 17,52 & 42,56 & \\
\hline Cement (kg/leto/preb.) & 776 & 450 & 184 & 1110 & 2966 & \\
\hline Jeklo (kg/leto/preb.) & 497 & 184 & 36 & 710 & 1730 & \\
\hline Aluminij (kg/leto/preb.) & 8,8 & 4,4 & 1,2 & 12,6 & 30,6 & \\
\hline Klor (kg/leto/preb.) & 8 & 4 & 0 & 11,4 & 27,9 & \\
\hline Zavarovane površine & $\begin{array}{c}0,06 \mathrm{ha} / \mathrm{preb} . \\
(19,4 \% \text { od } \\
2927 \mathrm{ha})\end{array}$ & 0,064 & 0,064 & & & \\
\hline Pozidane površine & $\begin{array}{c}0,03 \mathrm{ha} / \mathrm{preb} . \\
(10,8 \% \text { od } \\
1626 \mathrm{ha})\end{array}$ & 0,04 & 0,05 & $\begin{array}{c}0,04 \mathrm{ha} / \mathrm{preb} . \\
(15,4 \% \text { od } \\
2325 \mathrm{ha})\end{array}$ & $\begin{array}{c}0,11 \text { ha/preb. } \\
(32,3 \% \text { od } \\
4878 \text { ha) } \\
\end{array}$ & \\
\hline Neto potreba po površini & $2,15 \mathrm{ha} / \mathrm{preb}$. & $\begin{array}{c}1,08 \mathrm{ha} / \\
\text { preb. }\end{array}$ & 0 & & & \\
\hline Les $\left(\mathrm{m}^{3} /\right.$ preb.) & 1,14 & 0,60 & 0,56 & 1,63 & 3,97 & \\
\hline Voda $\left(\mathrm{m}^{3} /\right.$ preb.) & 187 & 66 & 65 & 267 & 561 & \\
\hline
\end{tabular}

Vir/Source: Žun (2013) 
Ugotovili smo, da je za MO Kranj v vseh treh poselitvenih tipih značilen tako globalno kot lokalno neuravnotežen materialni razvoj. V nadaljevanju zato predstavljamo nekatere napovedi in dodatne scenarije, kako odpraviti ne-trajnostno naravnan razvoj do leta 2050. Večina razvojnih dokumentov obravnava obdobje do leta 2020 in naprej do leta 2050. Z nadaljevanjem pričakovanih trendov se bodo ES v naslednjem desetletju ob najbolj optimističnih napovedih povečale za $4,5 \%$, nekatere napovedi pa omenjajo celo do $22 \%$-no povečanje (Dawkins in sod., 2008). Na podlagi predlaganih omilitvenih ukrepov lahko pričakujemo $2 \%$-no zmanjšanje ES (zaustavitev rasti).

Ob upoštevanju trajnostnih ukrepov bi dosegli največje zmanjšanje ES na suburbaniziranem območju (2,41 gha/preb.), manjše na območju podeželja (1,988 gha/preb.) in najmanjše na območju strnjenega mestnega jedra (1,978 gha/preb.). Za celotno MO Kranj lahko pričakujemo povprečno zmanjšanje ES za 2,219 gha/preb., to je za $35 \%$ manj kot leta 2008. Predvideni ukrepi niso zadostni za tolikšno zmanjšanje ES, da bi dosegli lokalno (0,76 gha/preb. bioproduktivnih površin) in tudi globalno (1,8 gha/preb.) uravnoteženost razvoja. Ukrepi in napovedi so bili izdelani na osnovi današnjega poznavanja energetskih, kmetijskih in okoljskih tehnologij.

$\mathrm{V}$ srednjeročnem obdobju bo potrebno aktivnosti usmeriti v spremembe vedenjskih vzorcev prebivalcev MO Kranj, še posebno na suburbaniziranem območju zaradi netrajnostnega vedenjskega vzorca tamkajšnjih prebivalcev. Srednjeročni ukrepi bi najbolj vplivali na obnovo in zamenjavo starih stavb. Največji potencial pri tem predstavlja obnova stanovanjskih blokov in starejših hiš na območju mestnega jedra, manj lahko pričakujemo od tega ukrepa na podeželju in suburbanem območju. Pri mobilnosti lahko pričakujemo največji učinek na podeželju in suburbanem območju, v mestnem jedru od teh ukrepov ne pričakujemo rezultatov. Na vseh območjih poselitve MO Kranj lahko pričakujemo učinke pri porabi hrane. Boljše rezultate je mogoče doseči tudi ob uvajanju centralno vodenih in koordiniranih pobud v vseh sektorjih, ob informiranju in ozaveščanju prebivalcev (recikliranje, varčna raba energije).

ES se bodo po trajnostnem scenariju v MO Kranj do leta 2020 zmanjšale za 13,8 \% (strnjeno mestno jedro $7,5 \%$, suburbanizirano območje $11,9 \%$, podeželje $22,1 \%$ ), do leta 2050 pa za $35 \%$ (strnjeno mestno jedro 36,4 \%, suburbanizirano območje 32,3\%, podeželje 30,1 \%) glede na leto 2008 (Žun, 2013). V srednjeročnem obdobju do leta 2020 lahko največ pričakujemo od ukrepov, povezanih z izkoriščanjem sončne energije na suburbaniziranem območju (zmanjšanje ES za -0,418 gha/preb.) in na podeželju (zmanjšanje ES za -0,781 gha/preb.). Učinki ukrepov, povezanih z energetskim knjigovodstvom in označevanjem gospodinjskih aparatov, so manjši, vendar jih lahko izvajamo takoj, brez dodatnih stroškov. Soproizvodnja električne energije v javnih stavbah ima na zmanjšanje ES manjši vpliv kot smo pričakovali, predvsem zaradi nestalnega obratovanja naprav in manjših moči kotlovnic. Učinek tega ukrepa lahko pričakujemo samo v strnjenem mestnem jedru in na suburbaniziranem območju. Ukrepi za zmanjšanje ES zaradi porabe hrane so najbolj usmerjeni v spremembe prehranjevalnih navad prebivalcev. Podobno naj bi spremembe vedenjskih vzorcev vplivale tudi na zmanjšanje ES, ki so posledica mobilnosti (preglednica 9). 
Preglednica 9: Pregled napovedi zmanjšanja ES po trajnostnem scenariju (2008-2050; gha/preb.) Table 9: Overview of the forecast decrease in ecological footprint according to sustainable scenario (2008-2050; gha per capita)

\begin{tabular}{|c|c|c|c|}
\hline & 2008 & 2020 & 2050 \\
\hline \multicolumn{4}{|l|}{ Raba energije } \\
\hline MO Kranj & 0,29 & $-0,07$ & $-0,145$ \\
\hline Strnjeno mestno jedro & 0,25 & $-0,062$ & $-0,125$ \\
\hline Suburbanizirano območje & 0,40 & $-0,01$ & $-0,20$ \\
\hline Podeželje & 0,33 & $-0,083$ & $-0,15$ \\
\hline \multicolumn{4}{|c|}{90 \%-no zmanjšanje ES, ki so posledica rabe energije do leta 2050} \\
\hline MO Kranj & 0,82 & - & $-0,738$ \\
\hline Strnjeno mestno jedro & 0,87 & - & $-0,783$ \\
\hline Suburbanizirano območje & 1,05 & - & $-0,945$ \\
\hline Podeželje & 0,38 & - & $-0,342$ \\
\hline \multicolumn{4}{|l|}{ Poraba hrane } \\
\hline MO Kranj & 1,89 & $-0,132$ & $-1,077$ \\
\hline Strnjeno mestno jedro & 1,62 & $-0,113$ & $-0,923$ \\
\hline Suburbanizirano območje & 1,93 & $-0,135$ & $-1,00$ \\
\hline Podeželje & 1,93 & $-0,135$ & $-1,100$ \\
\hline \multicolumn{4}{|l|}{ Voda } \\
\hline MO Kranj & 0,01 & $-0,005$ & - \\
\hline \multicolumn{4}{|l|}{ Učinkovita mobilnost } \\
\hline MO Kranj & 0,56 & $-0,218$ & $-0,269$ \\
\hline Strnjeno mestno jedro & 0,29 & $-0,123$ & $-0,147$ \\
\hline Suburbanizirano območje & 0,54 & $-0,211$ & $-0,265$ \\
\hline Podeželje & 0,84 & $-0,326$ & $-0,396$ \\
\hline MO Kranj & 0,03 & $+0,00$ & $+0,01$ \\
\hline \multicolumn{4}{|l|}{ Grajeno okolje } \\
\hline \multicolumn{4}{|l|}{ Skupaj } \\
\hline MO Kranj & 6,34 & $6,34-0,873=\mathbf{5 , 4 6 7}$ & $6,34-2,219=\mathbf{4 , 1 2 1}$ \\
\hline Strnjeno mestno jedro & 5,44 & $5,44-0,407=\mathbf{5 , 0 3 3}$ & $5,44-1,978=\mathbf{3 , 4 6 2}$ \\
\hline Suburbanizirano območje & 7,76 & $7,76-0,908=\mathbf{6 , 7 5 2}$ & $7,66-2,41=\mathbf{5 , 2 5}$ \\
\hline Podeželje & 6,60 & $6,60-1,458=\mathbf{5 , 1 4 2}$ & $6,60-1,988=\mathbf{4 , 6 1 2}$ \\
\hline
\end{tabular}

Vir/Source: Žun (2013)

Poraba snovi in energije v MO Kranj je čezmerna, zato je potrebno prilagoditve usmeriti v naslednje smeri:

- minimizacija antropogenih snovno-energijskih tokov (energetska sanacija stavb na vseh poselitvenih območjih, revitalizacija degradiranih površin v strnjenem mestnem jedru, spremenjeni načini prehranjevanja); 
- povečevanje rabe obnovljivih virov energije (fotovoltaični sistemi, toplotne črpalke na vseh poselitvenih območjih, uporaba lesne biomase za proizvodnjo toplote $\mathrm{v}$ javnih stavbah);

- raznovrsten mozaik učinkovitih načinov prevoza namesto prevladujoče rabe avtomobila: ob okolju bolj prilagojenem avtomobilu še železnica, avtobus in kolo (novi tir železniške proge, kolesarske poti, javni prevoz, predvsem na podeželju in suburbanem območju);

- namesto snovno-linearnega, pretočnega gospodarstva, krožno gospodarstvo, ki bo zasnovano na ponovni rabi, reciklaži surovin (predvideni center za ravnanje z odpadki na Polici).

Gospodarstvo v MO Kranj je globalizirano in se bo moralo tudi s strateškega vidika prilagoditi novim smernicam trajnostnega razvoja:

- temeljita energetsko-okoljska posodobitev, zasnovana na prilagajanju podnebnim spremembam in zmanjševanju emisij toplogrednih plinov; ključni trendi v smeri nizkoentropijske in nizkoogljične družbe;

- prepoznavanje in vključevanje vseh okoljsko-podnebnih zunanjih stroškov v cene proizvodov in storitev, kar bo med drugim bistveno spremenilo cene virov energije in ekosistemski pomen bioproduktivnih zemljišč;

- večji prispevek gospodarstva (slovenskega, kranjskega) $\mathrm{k}$ iskanju trajnostno optimalnih sodobnih izzivov širše pojmovane nacionalne varnosti, katere pomembne sestavine so vodna in prehranska varnost (težnja $\mathrm{k}$ samooskrbi, ohranjanje že strateško kritičnega razmerja med kmetijskimi, gozdnimi in pozidanimi površinami), povečanje energetske varnosti z rabo domačih virov energije.

Celotna MO Kranj mora sama prevzeti nadzor nad razvojnim procesom, prebivalci morajo začeti aktivno in odgovorno sodelovati ter prevzemati odgovornost pri načrtovanju in izvajanju aktivnosti trajnostnega razvoja. 
Preglednica 10: Pregled napovedi zmanjšanja OP na področju $\mathrm{CO}_{2}$ po trajnostnem scenariju (2008-2050)

Table 10: Overview of the forecast reduction of $\mathrm{CO}_{2}$ emissions according to sustainable scenario (2008-2050)

\begin{tabular}{|c|c|c|c|c|}
\hline Kazalec OP & \begin{tabular}{|l} 
MO Kranj \\
$(2008)$
\end{tabular} & MO Kranj 2020 & \multicolumn{2}{|l|}{ MO Kranj (do 2050) } \\
\hline Emisije $\mathrm{CO}_{2}$ & 12,25 & & \multicolumn{2}{|l|}{1,7} \\
\hline t/leto/preb. & & $\begin{array}{l}\text { Do leta } 2020 \text { je mogoče } \\
\text { doseči } 20 \% \text {-no } \\
\text { zmanjšanje emisij } \\
\text { toplogrednih plinov na } \\
\text { lokalni ravni.* }\end{array}$ & \multicolumn{2}{|c|}{$\begin{array}{l}\text { Da bo do leta } 2050 \text { mogoče doseči } \\
\text { cilj } 80-95 \% \text { skupnega zmanjšanja } \\
\text { emisij toplogrednih plinov, je treba } \\
\text { stroškovno učinkovito in postopno do } \\
\text { leta } 2030 \text { za } 40 \% \text { zmanjšati emisije } \\
\text { toplogrednih plinov na lokalni ravni v } \\
\text { primerjavi z letom 1990, do leta } 2050 \\
\text { pa za } 80 \% .^{* *}\end{array}$} \\
\hline & & 10-kratno zmanjšanje & & \\
\hline & & $-28 \%$ & \multicolumn{2}{|c|}{$50 \%$-no zmanjšanje rabe fosilnih goriv } \\
\hline \multicolumn{5}{|l|}{ Dodatni ukrepi } \\
\hline & MO Kranj & Strnjeno mestno jedro & Suburbanizirano območje & Podeželje \\
\hline & \multicolumn{4}{|c|}{ Zmanjšanje emisij $\mathrm{CO}_{2}(\mathrm{t} /$ leto) - cilj doseči do leta 2020} \\
\hline $\begin{array}{l}\text { Operativni program } \\
\text { zmanjševanja emisij } \\
\text { toplogrednih plinov, } 2003\end{array}$ & 8362 & 3565 & 3388 & 1409 \\
\hline $\begin{array}{l}\text { Dodatni ukrepi v } \\
\text { gospodinjstvih }\end{array}$ & 66.036 & 30.202 & 22.747 & 9106 \\
\hline $\begin{array}{l}\text { Skupaj na poselitveno } \\
\text { območje }\end{array}$ & 74.398 & 33.767 & 26.135 & 10.425 \\
\hline Skupaj/preb. & 1,43 & $\mathbf{1 , 5 2}$ & 1,23 & 1,18 \\
\hline
\end{tabular}

Vir/Source: Žun (2013)

Opombe:

*Ob popolnem in uspešnem izvajanju prenovljenega načrta za energijsko učinkovitost in ob uresničitvi cilja 20 \%-ne energetske učinkovitosti bi lahko EU presegla trenutni cilj $20 \%$ zmanjšanja emisij in dosegla $25 \%$ zmanjšanje.

**Na podlagi dosedanjih dosežkov mora EU sedaj začeti oblikovati ustrezne strategije za napredek v tej smeri, vse države članice pa morajo čim prej razviti svoje nacionalne načrte za nizkoogljično gospodarstvo. 
Preglednica 11: Pregled napovedi zmanjšanja OP na ostalih področjih po trajnostnem scenariju (2008-2050)

Table 11: Overview of the forecasted decrease of environmental space in other areas according to sustainable scenario (2008-2050)

\begin{tabular}{|c|c|c|c|}
\hline Kazalec OP & $\begin{array}{l}\text { MO Kranj } \\
(2008)\end{array}$ & $\begin{array}{l}\text { MO Kranj } \\
2020\end{array}$ & MO Kranj (do 2050) \\
\hline Cement (kg/leto/preb.) & 776 & 450 & $184(50$ \%-no zmanjšanje glede na leto 1990$)$ \\
\hline Jeklo (kg/leto/preb.) & 497 & $-20 \%$ & 36 (50 \%-no zmanjšanje glede na leto 1990) \\
\hline Aluminij (kg/leto/preb.) & 8,8 & $-23 \%$ & 1,2 (50 \%-no zmanjšanje glede na leto 1990) \\
\hline Klor (kg/leto/preb.) & 8 & & $\begin{array}{l}0 \text { (omejiti rabo umetnih gnojil in fitofarmacevtskih } \\
\text { sredstev)* }\end{array}$ \\
\hline $\begin{array}{l}\text { Zavarovane površine } \\
\text { (ha/preb.) }\end{array}$ & 0,06 & & $\begin{array}{l}\text { 0,064 (10 \% popolnoma zavarovanih območij, } 10 \\
\% \text { delno zavarovanih gozdnih območij, } 10 \% \text { za } \\
\text { zagotovitev biotske raznovrstnosti in upravljanju z } \\
\text { vodnimi viri) }\end{array}$ \\
\hline $\begin{array}{l}\text { Pozidane površine } \\
\text { (ha/preb.) }\end{array}$ & 0,03 & & $\begin{array}{l}0,051 \text { (največ } 8 \% \text { površin; urbane površine se } \\
\text { širijo samo na degradiranih površinah) }\end{array}$ \\
\hline $\begin{array}{l}\text { Neto potreba po površini } \\
\text { (ha/preb.)** }\end{array}$ & 2,15 & & $\begin{array}{l}0 \text { (globalni cilj do leta } 2050 \text { je } 0,281 \text { ha/preb.; } \\
\text { zmanjšati porabo mesa za } 50-70 \% \text { ) }\end{array}$ \\
\hline Les $\left(\mathrm{m}^{3} /\right.$ preb.) & 1,14 & & 0,56 (10 \% delno zavarovanih gozdnih območij) \\
\hline Voda $\left(\mathrm{m}^{3} / \text { preb. }\right)^{* * *}$ & 109 & $-20 \%$ & 65 (omejiti porabo na $10 \%$ razpoložljive vode) \\
\hline
\end{tabular}

Vir/Source: Žun (2013)

Opombe:

* Po nekaterih ocenah se bo zmanjšala količina pridelka za 10-30\%. Raba umetnih gnojil in fitofarmacevtskih sredstev onesnažuje tudi vodne vire, ki jih metoda OP obravnava kot regionalne vire.

**VEvropi je na voljo 0,4 ha/preb. kmetijskih zemljišč, svetovno povprečje je 0,24 ha/preb. *** Skupna izdatnost obstoječih (187 $\mathrm{m}^{3} /$ leto/preb.) in načrtovanih $\left(128 \mathrm{~m}^{3} /\right.$ leto/preb.) virov je ocenjena na približno $315 \mathrm{~m}^{3} /$ leto/preb.

\section{SKLEP}

MO Kranj z različnimi oblikami poselitve, porabe naravnih virov in značilnostmi gospodarskega razvoja predstavlja vzorčni primer geografsko pestre alpske in predalpske občine v Sloveniji. S sistemskim pristopom merjenja ekoloških sledi in okoljskega prostora na ravni mestne občine lahko spodbudimo lokalno okolje k aktivnemu sprejemanju trajnostnostnih rešitev pri načrtovanju razvoja. Posledično bi lahko zmanjševali velike posege v okolje, ki so v nasprotju z zmogljivostjo okolja občine, regije, države, planeta.

Na ravni MO Kranj ni statističnih podatkov, ki bi jih bilo mogoče uporabiti za klasične postopke izračuna ES in OP, zato je bil za posamezne vplive na okolje (promet, poraba 
hrane in energije) potreben preračun iz dostopnih statističnih podatkov. Za izračun ES in OP v različnih geografskih območjih MO Kranj smo poleg metode anketiranja uporabili tudi druge dodatne metodološke prijeme, potrebne za ugotavljanje pritiskov na okolje posameznih gospodinjstev in drugih uporabnikov okoljskih virov. Ključni empirični rezultati so naslednji:

1. Poselitvena območja MO Kranj (strnjeno mestno jedro, suburbanizirano območje in podeželje) se tako po porabi naravnih virov kot po obremenjevanju sestavin okolja medsebojno razlikujejo, različni tipi poselitve MO Kranj vplivajo na obseg in sestavo ES. Te se po poselitvenih območjih pomembno razlikujejo (strnjeno mestno jedro 5,44 gha/ preb., suburbanizirano območje 7,76 gha/preb., podeželje 6,60 gha/preb.).

2. Za zmanjšanje ES in OP na preučevanih območjih je treba upoštevati dejavnike, kot so način poselitve, gospodarski sistemi, dnevne migracije, socialna sestava, in glede na te dejavnike je potrebno specifično trajnostno ukrepati. Na podeželju so izrazito večje ES pri mobilnosti v primerjavi z ostalima poselitvenima tipoma (strnjeno mestno jedro 0,29 gha/preb., suburbanizirano območje 0,56 gha/preb., podeželje 0,84 gha/preb.). Na suburbaniziranem območju so izrazito večje snovne ES v primerjavi z ostalima območjema (strnjeno mestno jedro 2,28 gha/preb., suburbanizirano območje 3,71 gha/preb., podeželje 2,99 gha/preb.). Najbližje trajnosti je vedenjski vzorec v strnjenem mestnem jedru, najbolj netrajnostni na suburbaniziranem območju, vendar so ES na vseh treh območjih bistveno nad trajno sprejemljivo ravnijo.

3. Različna poselitvena, gospodarska in socialna sestava posameznih območij pomembno vpliva na izbiro ukrepov za zmanjšanje ES in OP. Predstavljeni ukrepi zmanjšanja ES imajo največje srednjeročne in dolgoročne učinke na podeželju (srednjeročno: strnjeno mestno jedro -0,41 gha/preb., suburbanizirano območje $-0,91$ gha/preb., podeželje $-1,46$ gha/preb.; dolgoročno: strnjeno mestno jedro -2,20 gha/preb., suburbanizirano območje $-3,46$ gha/preb., podeželje $-4,60$ gha/preb.). Največji vpliv na učinkovitost predvidenih ukrepov ima možnost uporabe obnovljivih virov energije in povečevanje učinkovite trajnostne mobilnosti. Vendar brez radikalnejšega zmanjševanja snovno-energijske porabe ne bo mogoče do leta 2050 doseči trajnostno sprejemljivih ES in porabe OP.

Metodi OP in ES se medsebojno dopolnjujeta. Metodo ES bi bilo potrebno nadgraditi $\mathrm{s}$ širšo presojo vplivov na okolje in ne omejiti zgolj na absorpcijo toplogrednih plinov, preračunano na $\mathrm{CO}_{2}$. Pri metodi ES prevladuje ekonomski vidik. Vpliv ekonomske sfere na socialno je večji kot na okoljsko. Socialni položaj prebivalcev mestnega jedra je v MO Kranj najslabši v primerjavi z ostalima območjema in tudi ES so na tem območju v MO Kranj najmanjše. Koncept OP ne omogoča dovolj natančne obravnave manjših, statistično ne dovolj dobro obdelanih sistemov (od spodaj navzgor, kot pri konceptu ES komponentna/ integralna metoda), v našem primeru različnih poselitvenih območij v MO Kranj, uporabna pa je npr. pri vrednotenju porabe klora, ki se v MO Kranj največ uporablja na podeželju (kmetijstvo), in rabe zemljišč. Metoda ES nam daje širšo sliko in je uporabna tudi v manjših opazovanih sistemih, metoda OP pa nam lahko pokaže konkretne cilje (npr. opustitev rabe fitofarmacevtskih sredstev). ES so pomemben kazalnik, ki ga lahko uporabimo za različno velike opazovane sisteme in, kakor smo dokazali, tudi za različne tipe poselitve. Metoda ES je dovolj uporabno znanstveno orodje pri vodenju politik odločanja in določevanja traj- 
nostnega razvoja. Še posebej metodo ES odlikuje združevanje v en sam skupen kazalec trajnostnega razvoja, kar omogoča tudi primerjave med občinami.

Glede na predstavljene izračune ES in OP lahko ugotovitve strnemo v naslednje:

- ES prebivalcev MO Kranj (6,34 gha/preb.) bistveno presegajo globalno razpoložljivo bioproduktivno površino (1,90 gha/preb.), so tudi nad slovenskim povprečjem $(5,30$ gha/preb.) in tudi večje od ostalih izračunov v Sloveniji (Ormož 4,30 gha/preb., Žalec 5,40 gha/preb., Naklo 4,57 gha/preb.); planetarna vrednost ES je 2,69 gha/preb.;

- izračun primanjkljaja ES pokaže tudi lokalno neuravnotežen materialni razvoj, saj so bioproduktivne površine manjše od ES (0,76 gha/preb. <6,34 gha/preb.);

- $\quad$ pri primerjavi ES po poselitvenih območjih MO Kranj ugotovimo najmanjše ES prebivalcev strnjenega mestnega jedra (5,44 gha/preb), nato prebivalcev podeželja (6,60 gha/ preb), največje ES povzročajo prebivalci suburbaniziranega območja (7,76 gha/preb);

- prebivalci podeželja imajo najmanjši ekološki primanjkljaj (3,41 gha/preb.), nato prebivalci strnjenega mestnega jedra (5,44 gha/preb.), največjega pa imajo prebivalci suburbaniziranega območja (7,22 gha/preb.);

- na osnovi primerjave ES in ekološkega primanjkljaja ugotavljamo, da je najprimernejši tip poselitve strnjeno mestno jedro, najbolj okoljsko obremenjujoč je suburbaniziran tip;

- za približevanje lokalnemu in globalnemu uravnoteženemu trajnostno sonaravnemu razvoju v Sloveniji bodo potrebni še izredno veliki napori in uporaba ter razvijanje novih tehnologij, ne glede na tip poselitve;

- ob uvajanju trajnostnega načina kmetovanja in opuščanju uporabe umetnih gnojil in fitofarmacevtskih sredstev ne smemo pričakovati povečanja površin za absorpcijo toplogrednih plinov;

- pri primerjavi sestave ES zaznavamo izredno visoke vrednosti za energijske površine (MO Kranj 3,01 gha/preb., Naklo 2,08 gha/preb., Žalec 2,55 gha/preb., Ormož 1,83 gha/preb.); še posebej izstopajo ES neposredne rabe zemeljskega plina.

\section{Viri in literatura}

Buitenkamp, M., Venner, H., Wams, T. E., 1993. Action plan for a sustainable Netherlands. Amsterdam, Friends of the Earth Netherlands, 186 str.

Carley, M., Spapens, P., 1998. Sharing the world: sustainable living and global equity in the 21 st century. London, Earthscan, 208 str.

Cohen, D., 2007. Earth Audit. New Scientist, 194, 2605, str. 36-43.

Dawkins, E., Paul, A., Barrett, J., Minx, J., Scott, K., 2008. Wales' ecological footprint scenarios to 2020. Stockholm, Stockholm Environment Institute, 81 str. URL: http:// www.sei-international.org/mediamanager/documents/Publications/Future/wales ecological footprint report 270508 final.pdf (Citirano 20. 8. 2014).

Erhart, V., 2007. Razlike v razvitosti območij glede na gostoto naseljenosti in upoštevanje tega kriterija pri izvajanju razvojnih politik v kmetijstvu. Magistrsko delo. Ljubljana, Ekonomska fakulteta, 86 str. URL: http://www.cek.ef.uni-lj.si/magister/erhart3443. pdf (Citirano 1. 8. 2014).

Footprint for cities. 2012. Global footprint network. URL: http://www.footprintnetwork. org/pt/index.php/GFN/page/footprint_for_cities (Citirano 9. 8. 2014). 
Hayward, T., 2006. Global justice and the distribution of natural resources. Political studies, 54, 2, str.349-369. DOI: 10.1111/j.1467-9248.2006.00606.x

Hille, J., 1997. The concept of environmental space: implications for policies, environmental reporting and assessments. København, European Environment Agency, 58 str.

Kokalj, Ž., Oštir, K., 2005. Ugotavljanje pokrovnosti iz satelitskih posnetkov in vrednotenje pokrajinskoekoloških tipov Slovenije. Geografski obzornik, 52, 4, str. 12-18.

Living planet report 2010. 2010. WWF in Global Footprint Network, 117 str. URL: http:// www.footprintnetwork.org/press/LPR2010.pdf (Citirano 1. 8. 2012).

Mastino, G., Buscema, I., Molinario, G., Ingino, F., 2004. Environmental space of Tuscany Region, Regione Toscana. Friends of the Hearth, 97 str.

Matijašič, D., 2003. Podatki o gozdnem prirastku. Zavod za gozdove Slovenije, Oddelek za gozdnogospodarsko načrtovanje. Ljubljana.

McLaren, D., 2003. Sustainable Europe and environmental space: achieving sustainability through the concept of environmental space. A trans-European project. London, Friends of the Earth.

Medved, S., 2006. Ekološke sledi neposredne rabe energije in mobilnosti v MOL. Poročilo raziskovalnega projekta Okoljska analiza in presoja prostorskega razvoja MOL v obdobju 1990-2015. Ljubljana, Filozofska fakulteta, 73 str.

Območna geodetska uprava, Izpostava Kranj. 2014. Izpis površin (stanje 1. 1. 2003).

Opschoor, J. B., Weterings, R., 1994. Environmental utilisation space: an introduction. Tijdschrift voor Milieukunde, 9, 4, str. 198-205.

Plut, D., 2006. Mesta in sonaravni razvoj: geografske razsežnosti in dileme urbanega sonaravnega razvoja. Ljubljana, Znanstvenoraziskovalni inštitut Filozofske fakultete, 226 str.

Plut, D., 2007. Sonaravni razvoj (napredek) in geografija. Dela, 28, str. 287-304. DOI: 10.4312/dela.28.20.287-304

Plut, D., 2008a. Okoljska globalizacija, nosilnost okolja in gospodarski razvoj. Znanstvena konferenca: Gospodarski razvoj - odprta vprašanja teorije in politike. Naše gospodarstvo, 54, 1-2, str. 63-69.

Plut, D., 2008b. Vrednotenje geografskega okolja in okoljska etika. Dela, 29, str. 63-75. DOI: $10.4312 /$ dela.29.5.63-75

Plut, D., 2011. Novi zeleni dogovor: možni ali edini izhod? Trajnostni razvoj. Delo, Sobotna priloga, leto 53, št. 204 (3. 9. 2011) .

Poročilo o stanju okolja v MO Kranj. 2007. Kranj, Mestna občina Kranj, 88 str.

Rezultati Popisa 2002. Naselja: prebivalstvo. Ljubljana, Statistični urad RS. URL: http:// www.stat.si/popis2002/si/rezultati_naselja_prebivalstvo.asp (Citirano 1. 8. 2014).

Rozman, R., 2008. Geografske zasnove za pripravo lokalnega programa varstva okolja občine Ormož. Magistrsko delo. Ljubljana, Filozofska fakulteta, Oddelek za geografijo, 209 str.

Rural development in the European Union - Statistical and economic information - Report 2006. 2006. European Commission, Directorate-General for Agriculture and Rural Development, 411 str. URL: http://ec.europa.eu/agriculture/agrista/rurdev2006/ index_en.htm (Citirano 1. 8. 2014).

Sachs, W., Loske, R., Linz, M., 1998. Greening the North: a post-industrial blueprint for ecology and equity. London, Zed Books, 247 str. 
Statistični letopis Republike Slovenije 2006. 2006. Ljubljana, Statistični urad RS. URL: http:// www.stat.si/letopis/index_vsebina.asp?leto=2006\&jezik=si (Citirano 5. 11. 2014).

Statistični letopis Republike Slovenije 2009. 2009. Ljubljana, Statistični urad RS. URL: https://www.stat.si/letopis/LetopisPrvaStran.aspx?leto=2009\&jezik=si (Citirano 5. 11. 2014).

Strategija trajnostnega razvoja Mestne občine Kranj 2008-2023. 2009. Kranj, Mestna občina Kranj, 118 str. URL: http://www.kranj.si/files/06_mestna_obcina/strategija_ razvoja_MO_Kranj/strategija_razvoja_-_koncna_verzija.pdf (Citirano 15. 9. 2014).

Sustainable development. 2009. European Commission. URL: http://ec.europa.eu/environment/eussd/ (Citirano 27. 10. 2014).

Wackernagel, M., Kitzes, J., Moran, D., Goldfinger, S., Thomas, M., 2006. The ecological footprint of cities and regions: comparing resource availability with resource demand. Environment and urbanization, 18, 1, str. 102-112. DOI: 10.1177/0956247806063978 Wackernagel, M., Rees, W., 1996. Our ecological footprint: reducing human impact on the Earth. Gabriola Islands (BC, Kanada), New Society Publishers, 160 str.

Wissenburg, M., 2006. Global and ecological justice: prioritising conflicting demands. Environmental values, 15, 4, str. 425-439.

Žun, Š., 2004. Ekološko sledenje razvoja lokalnih skupnosti. Magistrsko delo. Ljubljana, Fakulteta za strojništvo, 108 str.

Žun, Š., 2013. Merjenje in vrednotenje trajnostnega razvoja lokalnih skupnosti z metodo ekoloških sledi in okoljskega prostora. Doktorsko delo. Ljubljana, Filozofska fakulteta, Oddelek za geografijo, 235 str.

\section{SYSTEMIC ENVIRONMENTAL EVALUATION OF SUSTAINABLE DEVELOPMENT OF SETTLEMENT AREAS IN KRANJ URBAN MUNICIPALITY}

\section{Summary}

Closed environmental system of Kranj Urban Municipality with its different settlement types, use of natural resources and economic development characteristics is an example of geographically varied alpine and pre-alpine Slovene municipality. An active approach to measuring ecological footprint and environmental space at the level of a municipality can encourage local communities to welcome actively sustainable solutions while planning the development of similar Slovene municipalities. Consequently, we can reduce major interventions in the environment that are not in accordance with the capacity of the environment of the municipality, region, planet.

On the level of the Kranj Urban Municipality, there is no useful statistical data which could be used for classical methods of calculating the ecological footprint and environmental space, so for the individual impacts on the environment (traffic, food consumption and energy) a recalculation was needed from available statistical data. Apart from the surveys, other methods were used to calculate ecological footprint and environmental space in the municipality, derived from the research of the envi- 
ronmental stress caused by individual households and by overusing environmental resources (Žun, 2013).

Sampled geographical areas (inner city, suburban area and surrounding countryside) of Kranj Urban Municipality differ in use of natural resources and in environmental stress level. Different settlement types in the municipality influence the scope and composition of ecological footprint. It differs significantly among settlement types (inner city 5,44 gha per capita, suburban area 7,76 gha per capita, countryside 6,60 gha per capita).

To decrease ecological footprint and environmental space, certain elements, such as settlement type, daily migrations, social composition, need to be taken into consideration for observed areas and some specific measures are needed. In the countryside area, the mobility ecological footprint is much higher than in other settlement types (inner city 0,29 gha per capita, suburban area 0,56 gha per capita, countryside 0,84 gha per capita). In suburban area, the material ecological footprint is much more important (inner city 2,28 gha per capita, suburban area 3,71 gha per capita, countryside 2,99 gha per capita). The strongest sustainable behaviour pattern is found in the inner city, the less sustainable one is found in suburban area.

Different settlement, economic and social composition of individual areas significantly influence the selection of measures for reducing ecological footprint and environmental space. Introduced measures for decreasing ecological footprint (Žun, 2013) produce most mid-term and long-term results in the countryside area (mid-term: inner city $-0,41$ gha per capita, suburban area $-0,91$ gha per capita, countryside $-1,46$ gha per capita; long-term: inner city $-2,20$ gha per capita, suburban area $-3,46$ gha per capita, countryside $-4,60$ gha per capita). Possibility to use renewable energy sources and increase efficient sustainable mobility have the highest influence on the efficiency of planned measures.

It is established that the methods of calculating environmental space and ecological footprint complement each other and that the ecological footprint method needs to be complemented with a wider evaluation of environmental influences, not only with the absorption of greenhouse gasses, calculated in $\mathrm{CO}_{2}$. The ecological footprint method is dominated by the economical influences. The influence of the economy on the social sphere is much stronger than the environmental. Compared to the other settlement areas in Kranj Urban Municipality, the social status of the inhabitants of the inner city is the worse, while at the same time ecological footprint in this settlement area is the smallest. The method does not allow an exact analysis of smaller, statistically not well covered systems (bottom-up as in ecological footprint component/integral method), in our case of different settlement types in Kranj Urban Municipality, but it can be used when evaluating chlorine consumption, for example, that is mostly used in the countryside areas in agriculture. The ecological footprint method gives a wider picture and can be used also in smaller systems, while the environmental space method can point to concrete goals (abandon the use of phytopharmaceuticals). Ecological footprint is an important indicator that can be used for different dimension scales and, as proven, for different settlement types. The ecological footprint method is useful enough as a scientific tool for managing decision policies and determining 
sustainable development. The ecological footprint method excels in particular with one single sustainable development indicator.

Given the results of the ecological footprint and the environmental space, the conclusions can be grouped in the following findings:

- Ecological footprint by inhabitants of Kranj Urban Municipality (6,34 gha per capita) significantly exceeds globally available bio-productive surface (1,90 gha per capita), it exceeds the average Slovene ecological footprint (5,30 gha per capita) as well as of other Slovene communes for which the data are available (Ormož 4,30 gha per capita, Žalec 5,40 gha per capita, Naklo 4,57 gha per capita); planetary value of the ecological footprint is 2,69 gha per capita.

- Calculation of ecological footprint deficit demonstrates also locally unbalanced development since bio-productive surfaces are smaller than ecological footprint $(0,76$ gha per capita $<6,34$ gha per capita).

- Comparison of ecological footprint of inhabitants of Kranj Urban Municipality shows that the ecological footprint is the smallest for inhabitants of inner city $(5,44$ gha per capita), followed by the inhabitants of the countryside ( 6,60 gha per capita), while the largest ecological footprint is produced by the inhabitants in the suburban area $(7,76$ gha per capita).

- Comparison of ecological deficit of inhabitants of Kranj Urban Municipality also shows that the ecological deficit is the smallest for inhabitants of the countryside $(3,41$ gha per capita), followed by the inhabitants of the inner city $(5,44$ gha per capita), while the largest ecological deficit is produced by the inhabitants of suburban area (7,22 gha per capita).

- Comparison of ecological footprint and ecological deficit proves that inner city is the most suitable settlement type, on the other hand, suburban type is the most stressful settlement type for the environment.

- A lot of effort as well as the use and development of new technologies will be needed to reach locally and globally balanced development more efficiently.

- Introducing sustainable farming, abandoning the use of fertilizers and phytopharmaceutical substances should not increase the surfaces for absorption of greenhouse gasses.

- Comparison of the composition of ecological footprint shows extremely high levels for energy surfaces (Kranj Urban Municipality 3,01 gha per capita, Naklo 2,08 gha per capita, Žalec 2,55 gha per capita, Ormož 1,83 gha per capita) with particularly high level of ecological footprint due to the direct use of natural gas.

\section{(Translated by the author)}

